\title{
Seismic basement in Poland
}

\author{
Marek Grad $^{1}$ Marcin Polkowski ${ }^{1}$
}

Received: 28 August 2014 / Accepted: 21 July 2015 / Published online: 10 September 2015

(C) The Author(s) 2015. This article is published with open access at Springerlink.com

\begin{abstract}
The area of contact between Precambrian and Phanerozoic Europe in Poland has complicated structure of sedimentary cover and basement. The thinnest sedimentary cover in the Mazury-Belarus anteclize is only $0.3-1 \mathrm{~km}$ thick, increases to 7-8 km along the East European Craton margin, and 9-12 km in the Trans-European Suture Zone (TESZ). The Variscan domain is characterized by a 1- to 2-km-thick sedimentary cover, while the Carpathians are characterized by very thick sediments, up to c. $20 \mathrm{~km}$. The map of the basement depth is created by combining data from geological boreholes with a set of regional seismic refraction profiles. These maps do not provide data about the basement depth in the central part of the TESZ and in the Carpathians. Therefore, the data set is supplemented by 32 models from deep seismic sounding profiles and a map of a high-resistivity (low-conductivity) layer from magnetotelluric soundings, identified as a basement. All of these data provide knowledge about the basement depth and of P-wave seismic velocities of the crystalline and consolidated type of basement for the whole area of Poland. Finally, the differentiation of the basement depth and velocity is discussed with respect to geophysical fields and the tectonic division of the area.
\end{abstract}

Keywords Basement - Thickness of sediments - Seismic velocities · Poland

Marek Grad

mgrad@mimuw.edu.pl

Marcin Polkowski

marcin.polkowski@igf.fuw.edu.pl

1 Faculty of Physics, Institute of Geophysics, University of Warsaw, Pasteura 7, 02-093 Warsaw, Poland

\section{Introduction}

The area of Poland covers a complicated contact between Precambrian Europe to the northeast and Phanerozoic terranes to the southwest (Fig. 1). The Trans-European Suture Zone (TESZ) between them is a major crustal-scale feature, which appears to be a deep-seated boundary reaching down to a depth of at least $200 \mathrm{~km}$ (e.g., Zielhuis and Nolet 1994; Schweitzer 1995; Wilde-Piórko et al. 2009). In Poland, the southwestern edge of the East European Craton (or the paleocontinent Baltica) is fault-bounded by the TeisseyreTornquist Zone (TTZ) which is continued in Scandinavia along the Sorgenfrei-Tornquist Zone (STZ). The structure and evolution of this area are still important tectonic problems in Europe north of the Alps (e.g., Dadlez 1982; Ziegler 1990; Pożaryski et al. 1992; Berthelsen 1998; Pharaoh 1999; Winchester and PACE TMR Network Team 2002; Winchester et al. 2002). In southern Poland, the younger Carpathian arc is an interrelated component of the Mediterranean arc basin, a complex, collisional environment between the European and Adriatic plates, which involved a variety of micro-continents and oceanic areas (e.g., Golonka et al. 2003).

The sedimentary cover of the EEC in northern Poland is rather thin, being only $0.3-1 \mathrm{~km}$ thick in the region of the Mazury-Belarus anteclize, but increases southwestwards to $7-8 \mathrm{~km}$ along the EEC margin. In the TESZ, the sedimentary layer attains a thickness of up to $9-12 \mathrm{~km}$. The Variscan domain is characterized by a 1 - to 2 -km-thick sedimentary cover, while the Carpathians are characterized by very thick sediments of up to c. $20 \mathrm{~km}$ (e.g., Guterch and Grad 2006). For this reason, the basement in the TESZ and in the Carpathians is not reached by boreholes, so its depth is available only from geophysical investigations, mostly from seismic profiling. In particular, seismic velocities in 
the basement could be used for discrimination between the crystalline and consolidated types of the crust. According to Dadlez (2006) and Dadlez et al. (2005), the crystalline crust is considered to consist of highly deformed metamorphic and igneous rocks, characteristic of Precambrian platforms. By contrast, the consolidated crust is composed of highly deformed but not necessarily metamorphosed sedimentary and subordinate igneous rocks, characteristic of the Paleozoic platform. The aim of this paper is to find the geometry of the seismic basement, its velocity, as well as the relationship between the crystalline basement, the consolidated basement, and the sedimentary cover in Poland.

\section{Geological and geophysical context}

Despite the ongoing discussion about the sedimentary cover and its basement in Poland, there is no consent between geologists on the tectonic subdivision and their structural
Fig. 2 Geological and seismic cross sections trough of the TransEuropean Suture Zone (TESZ) in Poland between the East European Platform (EEP) and West European Platform (WEP). a Location map of seismic profiles. b Geological cross section along line $\mathrm{AA}^{\prime}$ with two tectonic subdivisions by Karnkowski (2008) and Żelaźniewicz et al. (2011). c, d Seismic sections beneath profiles 1-VI-66, M-7, and P4. Note basement velocity differentiation: about $6.1 \mathrm{~km} / \mathrm{s}$ for the EEP and about $5.8 \mathrm{~km} / \mathrm{s}$ for the WEP. Basement in the TESZ area is not reached by boreholes (see dashed pink lines at depth of $5 \mathrm{~km}$ ), so its depth and velocity is available only from seismic profiles. FSB Fore-Sudetic Block, K-P Synclinorium Kościerzyna-Puławy Synclinorium, MPA Mid-Polish Anticlinorium, NSS North-Sudetic Synclinorium, Sz-M Synclinorium Szczecin-Miechów Synclinorium, WEP West European Platform, WS Western Sudetes, Compilation from Karnkowski (2008), Żelaźniewicz et al. (2011), and Grad et al. $(1991,2003 a, b)$

interpretation. An example of such a discordance could be illustrated for geological cross sections through the TransEuropean Suture Zone (TESZ) in Poland, between the East European Platform (EEP) and the West European Platform

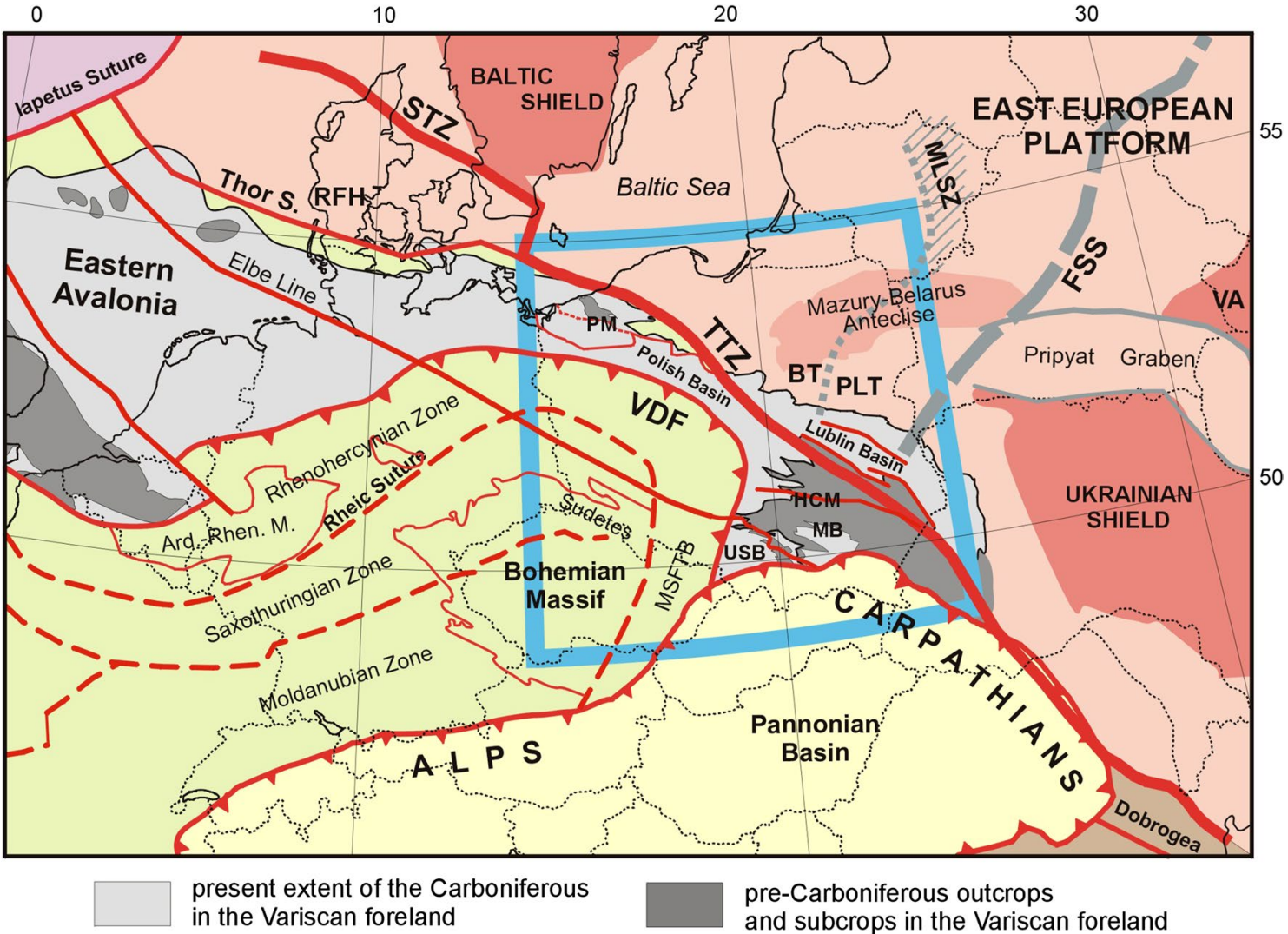

Fig. 1 Tectonic sketch of pre-Permian Central Europe in contact with the East European Platform, Variscides, and Alpine orogen. The blue frame shows the location of the study area in Poland. Compiled mainly from: Pożaryski and Dembowski (1983), Ziegler (1990), Winchester et al. (2002), Narkiewicz et al. (2011), Cymerman (2007), and Skridlaite et al. (2006). Ard.-Rhen. M. Ardenno-Rhenish Massif, BT Baltic Terrane, FSS Fennoscandia-Sarmatia Suture, HCM Holy Cross
Mountains, $M B$ Małopolska Block, MLSZ Mid-Lithuanian Suture Zone, MSFTB Moravian-Silesian Fold-and-Thrust Belt, PLT PolishLatvian Terrane, $P M$ Pomerania Massif, $R F H$ Ringkobing-Fyn High, STZ Sorgenfrei-Tornquist Zone, Thor S. Thor Suture, TTZ TeisseyreTornquist Zone, USB Upper Silesian Block, VA Voronezh Anteclise, $V D F$ Variscan Deformation Front 


\begin{tabular}{|c|c|c|c|c|}
\hline NSS ws & $\begin{array}{l}\text { Fore-Sudetic } \\
\text { Monocline }\end{array}$ & $\begin{array}{c}\text { Mogilno } \\
\text { Synclinorium }\end{array}$ & $\begin{array}{l}\text { Pomeranian } \\
\text { Synclinorium }\end{array}$ & East-European Platform \\
\hline $\begin{array}{l}\text { Karnkowski } \\
2008\end{array}$ & Variscan & & Caledonian & Precambrian basement \\
\hline
\end{tabular}

\begin{tabular}{|c|c|c|c|c|c|}
\hline NSS FSB & $\begin{array}{l}\text { Fore-Sudetic } \\
\text { Monocline }\end{array}$ & $\begin{array}{c}\text { Sz-M } \\
\text { Synclinorium }\end{array}$ & MPA & $\begin{array}{c}\text { K-P } \\
\text { Synclinorium }\end{array}$ & $\begin{array}{l}\text { Mazury-Podlasie } \\
\text { Monocline }\end{array}$ \\
\hline $\begin{array}{l}\text { Żelaźniewicz } \\
\text { et al. } 2011\end{array}$ & Variscan & $\begin{array}{c}\text { Trans-E } \\
\text { sutur }\end{array}$ & $\begin{array}{l}\text { uropean } \\
\text { e zone }\end{array}$ & Prece & mbrian basement \\
\hline
\end{tabular}

(b)
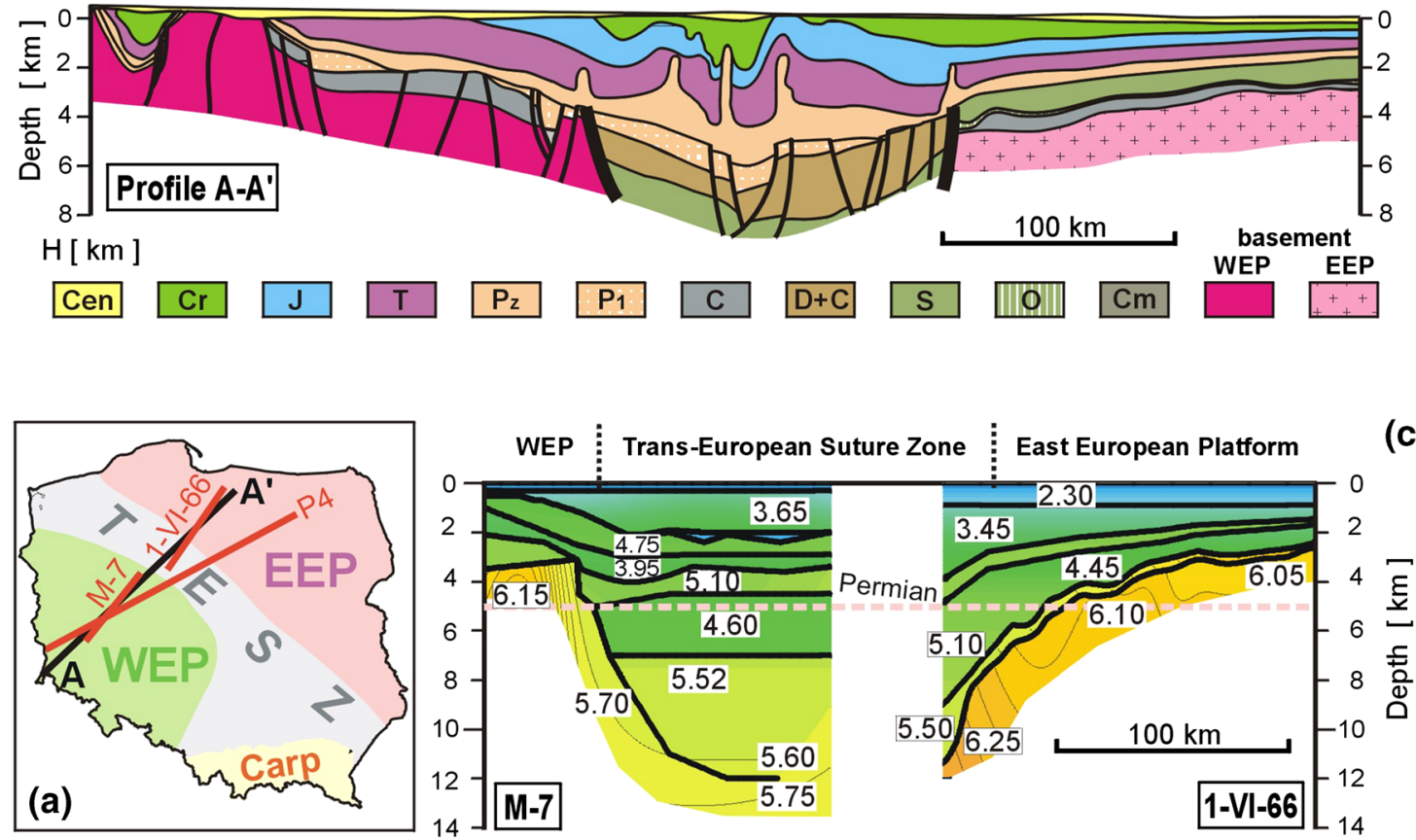

(c)
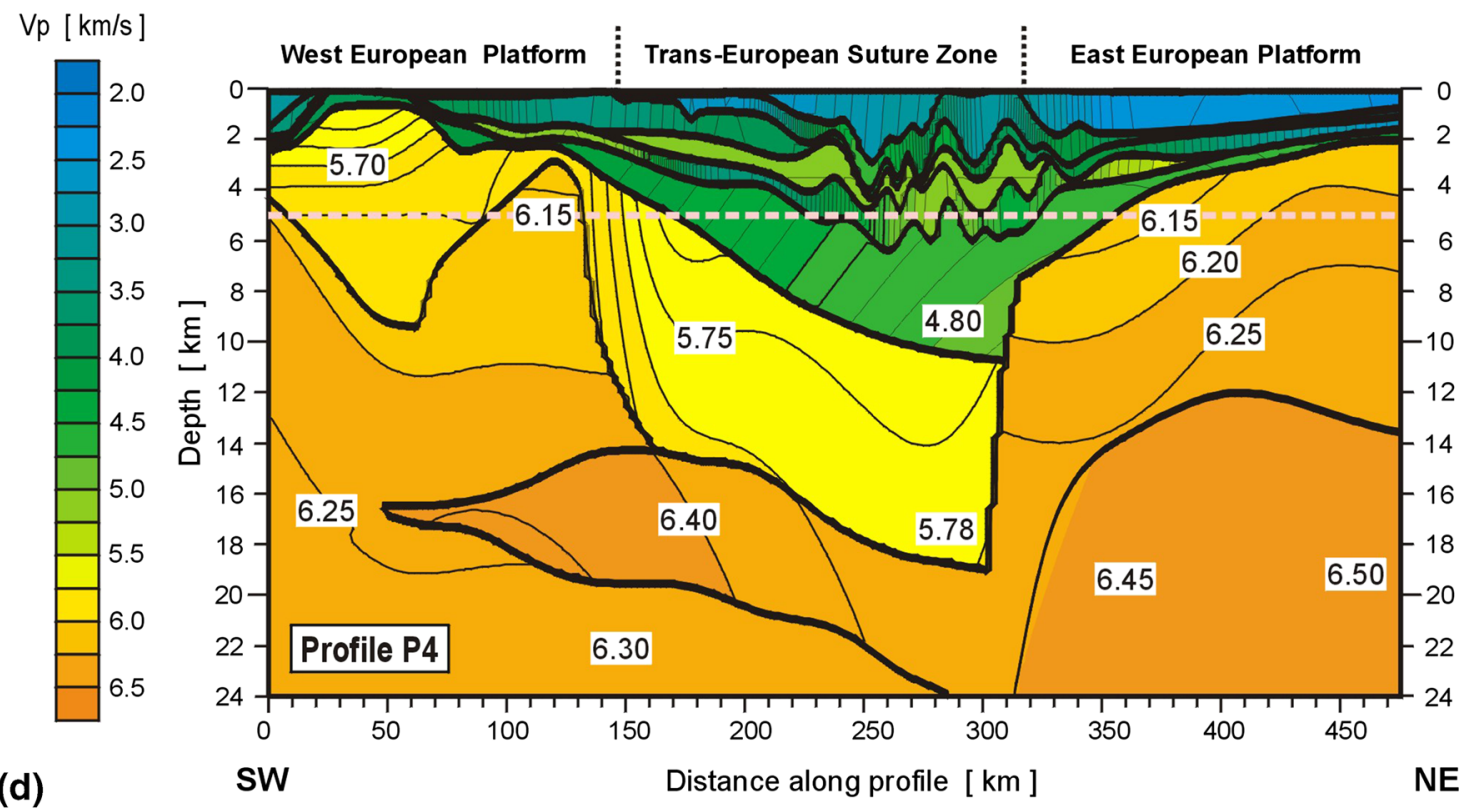

(d)
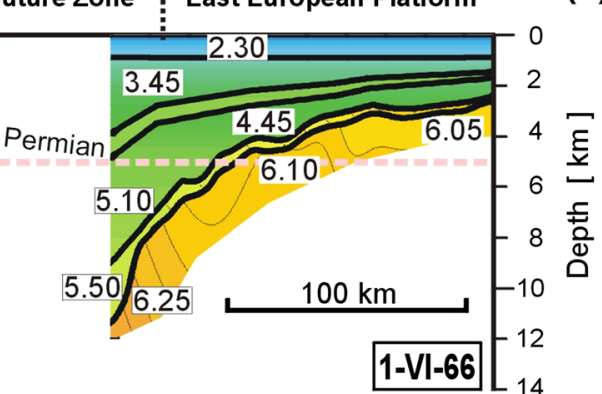

$\frac{\bar{\varepsilon}}{\frac{5}{D}}$


(WEP), as shown in Fig. 2. The same geological cross section along line $\mathrm{AA}^{\prime}$ (Fig. 2a) is interpreted in a different way by Karnkowski (2008) and Żelaźniewicz et al. (2011). Two tectonic subdivisions (Fig. 2b) differ both in the sedimentary cover and in the basement. Another geological regional subdivision of the Polish Lowlands was proposed by Narkiewicz and Dadlez (2008). The subdivision by Żelaźniewicz et al. (2011) was commented on and criticized by Narkiewicz (2012), and the discussion still seems to be far from finalized.

Seismic cross sections for profiles M-7, 1-VI-66, and P4, all close to line $\mathrm{AA}^{\prime}$, are shown in Fig. 2c, d. The sedimentary cover along the geological cross section (Fig. 2b) and seismic cross section along the P4 profile (Fig. 2d) show similar sequences of layers, including complicated Permian (Zechstein) salt diapirs and salt pillows in the TESZ (Krzywiec 2006a, b; Mazur et al. 2005). However, the major structural features of the seismic profiles are the basement depth and its velocity differentiation: c. $6.1 \mathrm{~km} / \mathrm{s}$ for the EEP and c. $5.8 \mathrm{~km} / \mathrm{s}$ for the WEP (Grad et al. 1991, 2003a, b). Differentiation of the basement is also observed in the complicated pattern of the Bouguer anomalies, the irregular pattern of the magnetic anomalies, electromagnetic properties, and the heat flow. All of these observations will be discussed at the end of the paper, together with the tectonic subdivisions of the area of Poland.

\section{Data}

In the area of Poland, the depth of the basement and its structure was studied using different methods and surveying techniques including deep geological boreholes, seismic refraction and reflection profiles, magnetic, gravity, and magnetotelluric measurements. Using these data, multiple studies regarding the basement depth were carried out and all such available studies are used in this paper and collectively displayed in Fig. 3. All map grids in this paper are recalculated to the same resolution of $0.02^{\circ}$ (longitude) by $0.01^{\circ}$ (latitude). That corresponds to semi-rectangular cells: $1112 \mathrm{~m}$ by $1281 \mathrm{~m}$ for northern Poland and $1112 \mathrm{~m}$ by $1459 \mathrm{~m}$ for southern Poland. Using grids with the same resolution allows for a simple manipulation and the performing of mathematical operations between multiple grids. All maps presented in this section are in the Lambert conic projection centered on $19.25^{\circ} \mathrm{E}$. All grid calculations are performed for the rectangular area: $13.8-24.5^{\circ} \mathrm{E}, 48.7-55.0^{\circ} \mathrm{N}$.

The complete basement depth map of the East European Craton in northeastern Poland was created by Skorupa (1974). This study covered an area of the EEC where the thickness of sediments is only $0.3-1 \mathrm{~km}$ thick in the region of the Mazury-Belarus anteclize, mostly less than $4 \mathrm{~km}$, and reaches c. $10 \mathrm{~km}$ on the edge of the East European
Fig. 3 The database for the basement depth and velocity in the area of Poland. a Basement depth from boreholes limited to $4.5 \mathrm{~km}$ depth (Małolepszy 2005; see text for more explanation); white color shows area with no data. b Depth of the seismic basement in northeastern Poland (Skorupa 1974) and depth of the basement (high-conductivity layer) from magnetotelluric investigations in Carpathians in southern Poland (Stefaniuk and Klityński 2007). c Basement depth beneath seismic refraction profiles; for each point along the profiles, a mask of $20 \mathrm{~km}$ radius was used to plot the basement depth; the white color shows an area with no refraction data. $\mathbf{d}$ Data coverage from all sources; colors correspond to a number of data sources available at a given location and the white color shows places with no data. e Averaged and interpolated basement depth from all available sources. f Interpolated P-wave velocity of the uppermost basement from seismic refraction profiles; the dotted line ellipse shows the area of anomalous velocity (anisotropy) discussed in the text. The data in the map c are from modern seismic refraction experiments/profiles: POLONAISE'97: Guterch et al. (1999); profile P1-Jansen et al. (1999); profile P2 - Janik et al. (2002); profile P3 - Środa and POLONAISE Working Group 1999 (1999); profile P4—Grad et al. (2003a, b); profile P5-Czuba et al. (2001); CELEBRATION 2000: Guterch et al. (2003): profiles CEL01 and CEL04-Środa et al. (2006); profile CEL02-Malinowski et al. (2005); profile CEL03-Janik et al. (2005); profile CEL05-Grad et al. (2006); profile CEL10-Grad et al. (2009); profiles CEL06, CEL11, CEL12, CEL13, CEL14, CEL21, CEL22, CEL23-Janik et al. (2009); SUDETES 2003: Grad et al. (2003a, b); profile S01-Grad et al. (2008); profiles S02, S03, S06-Majdański et al. (2006); OTHRER profiles: LT-2, LT-4, LT-5Grad et al. (2005); profile LT-7-Guterch et al. (1994); profiles M-7, M-9—Grad et al. (1991); profile TTZ—Grad et al. (1999); profile PANCAKE—Starostenko et al. (2013); profile 1-VI-66 — Grad et al. (1990)

Craton (see Fig. 3b, NE Poland). The study was based on data from geological boreholes and the set of regional seismic refraction profiles available at that time. In our elaboration, a corresponding mask for this map is calculated as having value 1 where data are available and value 0 elsewhere. This map covers $42.1 \%$ of the area of Poland.

A second basement depth map was compiled, based on geological boreholes data, using maps from the geological atlas of horizontal cuttings (Kotański 1997; Piotrowska et al. 2005; Małolepszy 2005; Nita et al. 2007; http://model3d.pgi.gov.pl/pages/miazszosc_podloze.htm). The compiled map was prepared down to $6 \mathrm{~km}$ depths, but knowing that borehole surveying has a limited range (due to the small amount of deep wells) only depths down to $4.5 \mathrm{~km}$ are considered in this paper. A proper mask for this map is calculated as having value 1 where data are available and the basement depth is shallower than $4.5 \mathrm{~km}$, and value 0 elsewhere. This map (Fig. 3a) covers $58.3 \%$ of the area of Poland.

Most of the Carpathian basement is not reached by boreholes. The use of the magnetotelluric method allowed for a study of the area where sediments are very thick-up to c. $25 \mathrm{~km}$. In magnetotelluric soundings, the basement is identified as a high-resistivity (low-conductivity) layer. The map of such a "basement" was prepared for the Carpathians using data form magnetotelluric soundings and 
(a)

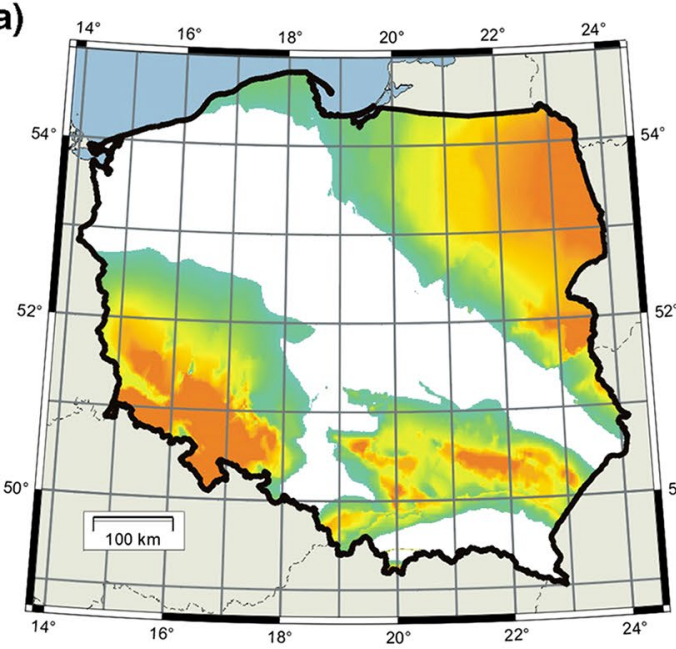

(c)

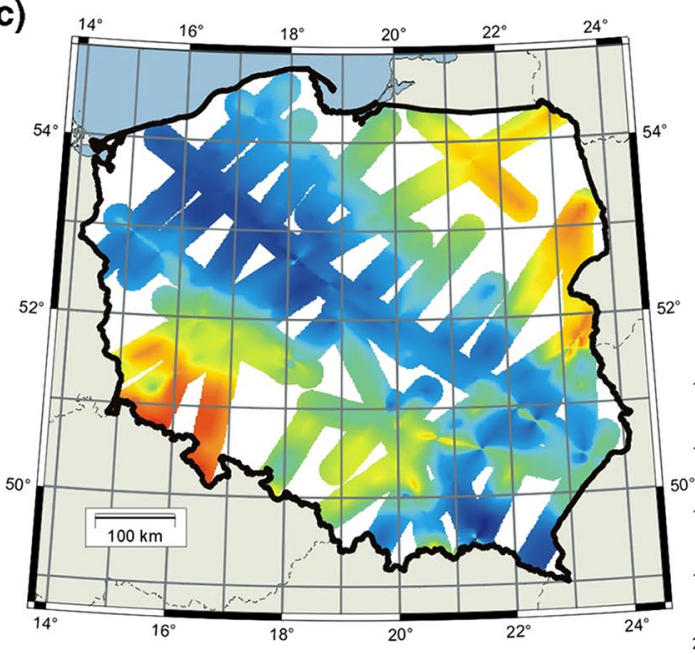

(e)

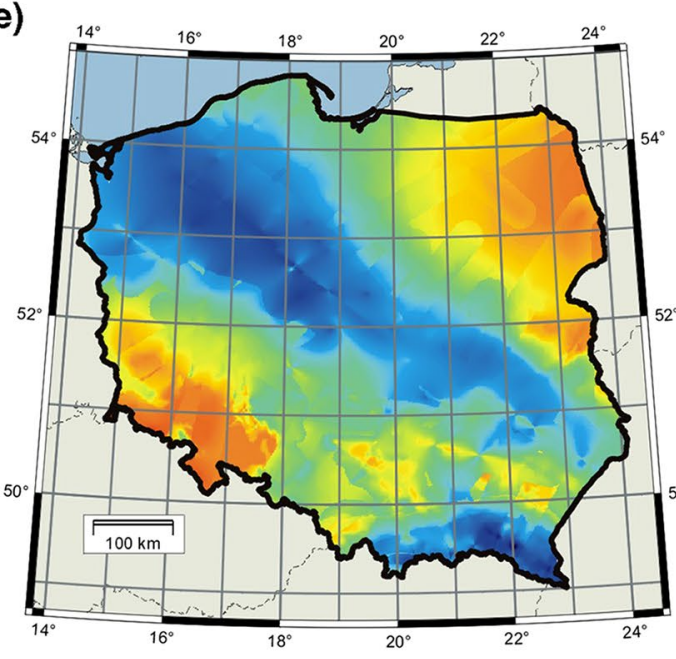

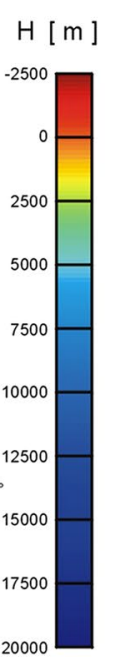

$H[m]$

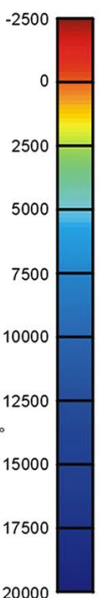

20000

$H[m]$

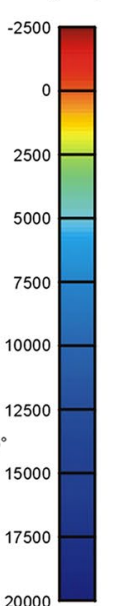

20000 boreholes by Stefaniuk and Klityński (2007). A proper mask for this map is calculated as having value 1 where data are available and value 0 elsewhere. This map is shown in Fig. 3b (southern Poland) and covers $6.6 \%$ of the area of Poland. (b)
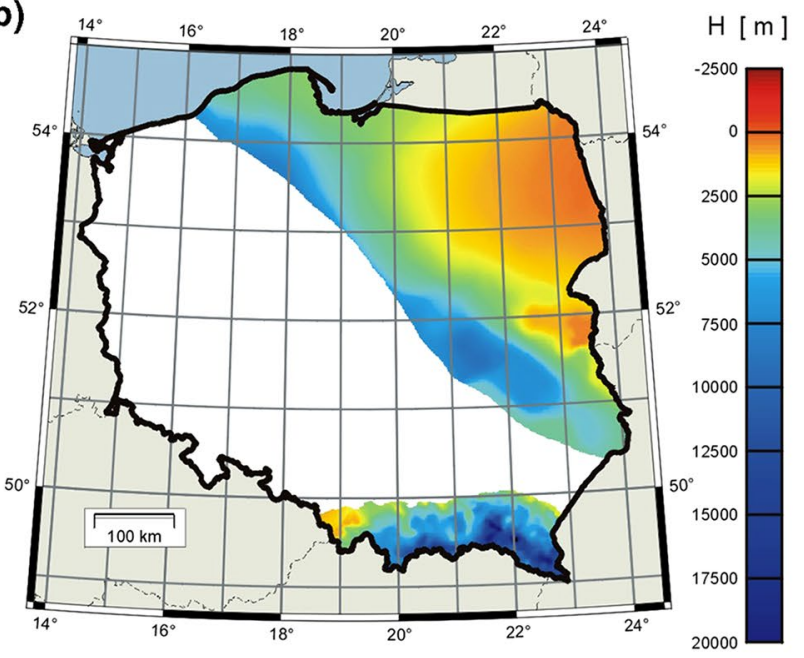

(d)

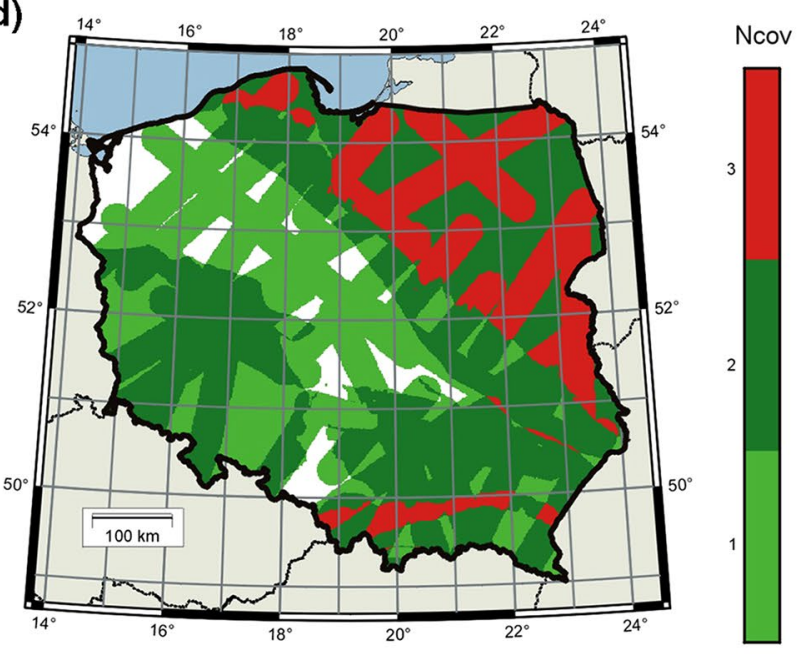

(f)

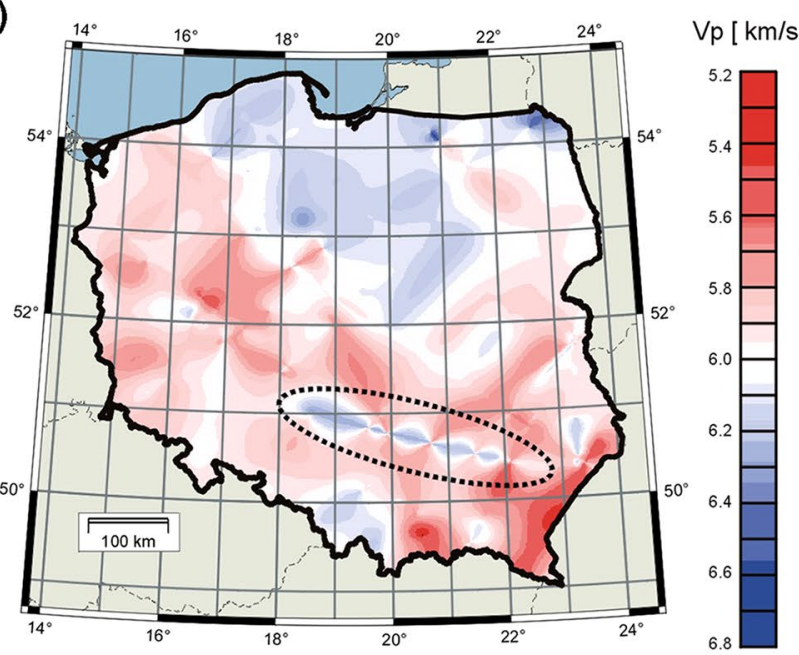

Combined together, these three maps (Fig. 3a, b) cover $75.9 \%$ of the area of Poland, but do not provide data about the basement depth in central Poland-in the area of the Trans-European Suture Zone (TESZ). The goal of this paper is to provide full knowledge of the basement depth 
for the whole area of Poland. To achieve this, the data set is supplemented by 32 models from deep seismic refraction profiles. The area of Poland is very well covered with modern seismic refraction profiles from multiple experiments, which are detailed in the figure caption of Fig. 3 with corresponding references.

For each profile, detailed 2D models of seismic velocities are analyzed in $1000 \mathrm{~m}$ (horizontal) by $100 \mathrm{~m}$ (vertical) resolution. Each model grid cell contains information about the P-wave seismic velocity and the layer number. The layer number allows tracking of geological layers for the profile. Additionally, the exact geographical locations of grid columns along the profile path are calculated. For each profile, the layer numbers corresponding to the basement are noted, allowing us to derive the basement depth for a certain location along the profile path.

The processing of all profiles provides a data set which includes latitude, longitude, basement depth, and P-wave velocity of the uppermost basement. This distinct distribution of points is later interpolated to a grid using GMT 5.1.1 surface command (Wessel and Smith 1991, 1998) with both interior and boundary tension parameters set to 0.5 , and the convergence limit set to 0.01 . Additionally, a grid mask is calculated as having value 1 in grid cells, within $20 \mathrm{~km}$ from any data point along the profile, and value 0 in other cases. A basement depth map calculated from seismic refraction profiles with an overlaying mask is shown in Fig. 3c. This map covers $72.3 \%$ of the area of Poland.

The resulting seismic basement map is created by combining the basement map created from seismic refraction profiles data with three additional basement depth maps available for parts of Poland. Figure $3 \mathrm{~d}$ shows the data availability map (sum of four masks mentioned above). $94.3 \%$ of the area of Poland is covered by at least one data source, $66.9 \%$ is covered by at least two data sources, and $19.0 \%$ is covered by at least three data sources. Finally, a combined basement map is obtained by averaging all four maps within the area of their availability and interpolating within gaps using the GMT 5.1.1 surface command with both interior and boundary tension parameters set to 0.5 , and convergence limit set to 0.01 . The resulting interpolated map covers $100 \%$ of the area of Poland and is shown in Fig. 3e.

Apart from the basement depth, the analysis of seismic refraction profiles provides the P-wave velocity of the uppermost basement. Figure $3 \mathrm{f}$ shows the result of interpolation of these data to a full grid. One issue is identified regarding the velocity map-in Fig. $3 f$ it is marked by ellipse. In southern Poland, one of the profiles (CEL14) provides $\mathrm{P}$-wave velocities much higher than for the other profiles around it, which are located nearly perpendicular to it. This is identified as the result of anisotropy in seismic
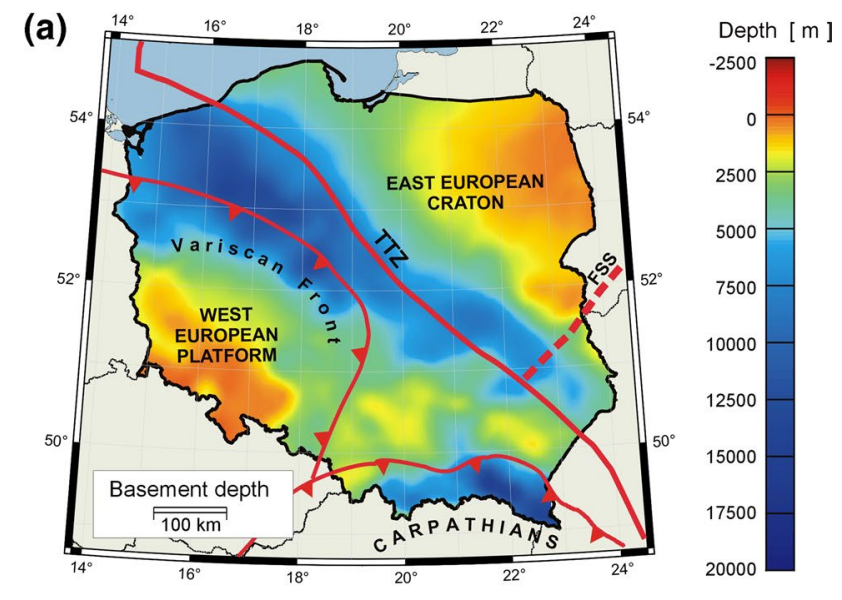

(b)
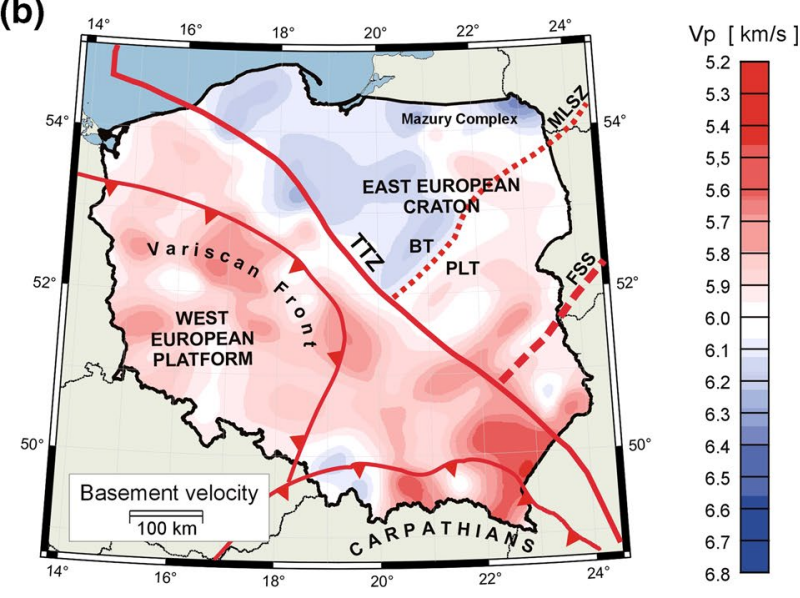

Fig. 4 The basement depth and P-wave velocity of the uppermost basement in the area of Poland. a Final basement depth map filtered with 30-km-radius boxcar filter. b Final P-wave velocity map of the uppermost basement filtered with a 30-km-radius boxcar filter. For abbreviations see Fig. 1

velocities in this area (Środa 2006), and for further analysis P-wave velocities for profile CEL14 are reduced by $6 \%$. After applying this change to the data sets, the P-wave map is recalculated.

Both basement depth and P-wave velocity of the uppermost basement maps are filtered using the GMT 5.1.1 grdfilter command for geographic grids with spherical distance calculation. A simple boxcar filter is used, where all weights are equal giving a mean value from a given radius (filter width)—in this case $30 \mathrm{~km}$. The final interpolated maps are presented in Fig. 4.

\section{Seismic basement: results}

The main features of the basement depth map in Poland (Fig. 4a) are a deep trough in the TESZ and a deep basement in the Carpathians. The depth difference of the 
(a)

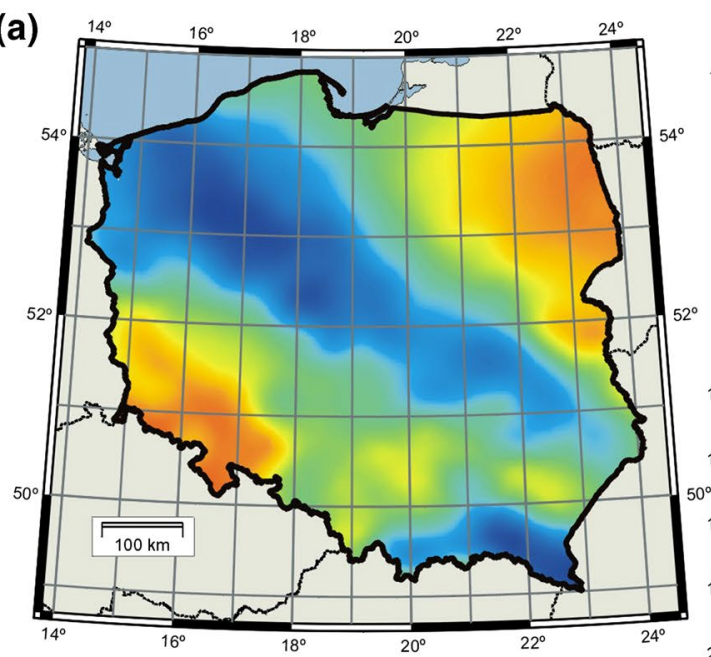

(c)

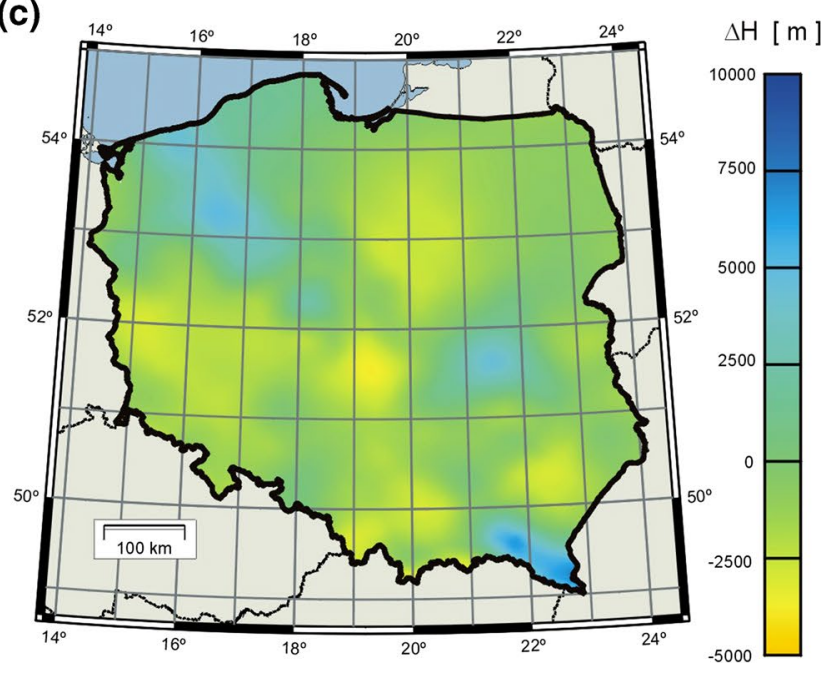

Fig. 5 Comparison of our basement depth with previous models for the area of Poland. a Final basement depth map filtered with 50-kmradius boxcar filter. b Difference between final basement map and global basement depth by Laske and Masters (1997). c Difference

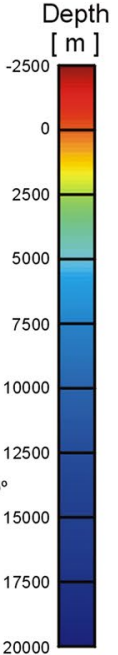

(b)

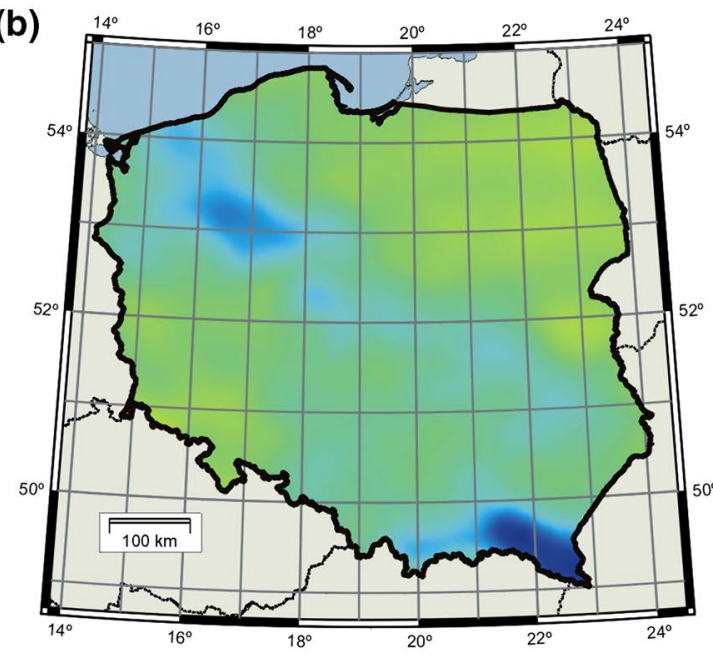

(d)

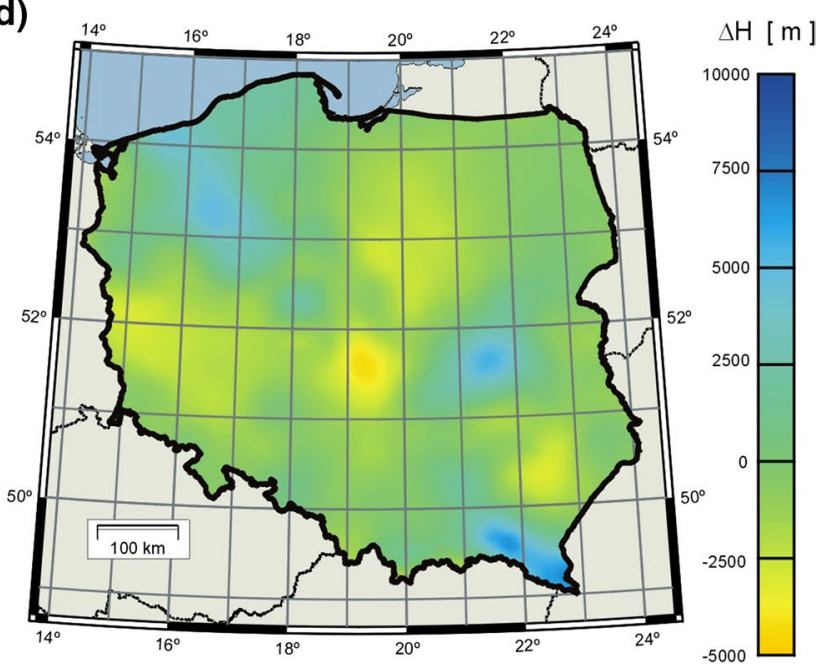

$\Delta \mathrm{H}[\mathrm{m}]$

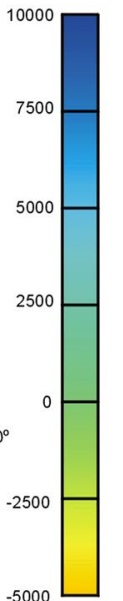

between final basement map and basement depth by Molinari and Morelli (2011). d Difference between final basement map and basement depth by Tesauro et al. (2008)

between EEC, WEP, and Carpathians is characterized by a 2- to 5 -km-deep basement.

This study is not the first one to provide a basement depth map for the area of Poland; however, it is the first to be dedicated to this region and prepared in such detail. The high-resolution basement depth map from this paper is compared to three other maps of lower resolution: one global map (Laske and Masters 1997) and two regional maps (Molinari and Morelli 2011; Tesauro et al. 2008). For a comparison of these maps and the map from our study, all are filtered and interpolated with the same $50-\mathrm{km}$ boxcar filter (Fig. 5).

Laske and Masters (1997) provide a global model of sediments' thickness with a resolution of $0.5^{\circ}$ by $0.5^{\circ}$. The thickness of sediments is provided and for a comparison with our basement depth, a Digital Elevation 
Model (Michalak 2004) has to be included. The difference between the map from this study and the map by Laske and Masters (1997) is shown in Fig. 5b. Molinari and Morelli (2011) provide a crustal model for the European Plate (EPcrust) with a resolution of $0.5^{\circ}$ by $0.5^{\circ}$, from which the thickness of sediments is taken. For a comparison with our basement depth, a Digital Elevation Model (Michalak 2004) has to be included to reduce the thickness to depth in relation to the sea level. The difference between the map from this study and the map by Molinari and Morelli (2011) is shown in Fig. 5c. Tesauro et al. (2008) provide a crustal model for Western and Central Europe and surroundings with $0.25^{\circ}$ by $0.25^{\circ}$ resolution from which the basement depth is taken for comparison. The difference between the map from this study and the map by Tesauro et al. (2008) is shown in Fig. 5d.

The comparison of our basement map with previously published maps shows many similarities, particularly for the EEC and the WEP. For these areas, differences are in the order of $1 \mathrm{~km}$ only for the Laske and Masters (1997) map, and of up to $3 \mathrm{~km}$ for the Molinari and Morelli (2011) and the Tesauro et al. (2008) maps. Much larger differences are observed in the TESZ, particularly in NW Poland, and in the Carpathians, particularly in their eastern part. For these areas, differences are larger for the Laske and Masters (1997) map, being up to 6-9 km, while for the Molinari and Morelli (2011) and the Tesauro et al. (2008) maps, the difference is in the order of 4-6 km. A recently published basement depth map for the Central European Basin System (Scheck-Wenderoth and Maystrenko 2013) also shows similar basement pattern in the TESZ area in NW Poland.

Complementary to the basement depth map is the P-wave velocity map of the uppermost basement (Fig. 4b). Velocities $V p>6 \mathrm{~km} / \mathrm{s}$ are observed in the EEC, north of the TTZ. However, this cratonic area is not homogeneous. Two distinct boundaries in velocity are marked in Fig. 4b by dashed lines that delineate the Fennoscandia-Sarmatia Suture (FSS) and the Mid-Lithuanian suture zone (MLSZ). The FSS is a suture between two once autonomous crustal segments/megablocks-Fennoscandia and Sarmatia (e.g., Bogdanova et al. 2006, 2008). The second boundary, SW-NE trending belt date from the initial assembly of this part of Baltica by terrane accretion, and is a feature that has been interpreted as the Mid-Lithuanian suture zone (MLSZ; e.g., Skridlaite and Motuza 2001; Skridlaitè et al. 2006). In the area of Lithuania, the MLSZ is $30-40 \mathrm{~km}$ wide and its continuation follows the border between Baltic terrane and Polish-Latvian terrane in the area of Poland (Cymerman 2007). The belt between the MLSZ and the FSS is characterized by significantly lower velocities of the uppermost basement. In northeastern Poland, along the state border, the relatively small areas with high P-wave velocities were found. They are interpreted as high-velocity magmatic intrusions beneath profile $\mathrm{P} 4$ and beneath the profile P5. Unfortunately, both intrusions are crossed only by one single profile, thus their size and shape could not be determined from these profiles alone. These intrusions are known as anorthosite bodies of Suwałki and Kętrzyn within the Paleoproterozoic (1.50-1.56 Ga) Mazury granitoid complex. The youngest magmatic Neoproterozoic-Paleozoic rocks in the region are intrusions of alkaline rocks (e.g., Tajno intrusion; Ryka 1984); however, they were not crossed by any of the profile. Accordingly they are not visible in the velocity map.

Southwest of the TTZ, velocities of the uppermost basement are significantly lower, being $V \mathrm{p}<6 \mathrm{~km} / \mathrm{s}$. Only in southern Poland, in the corner between the Variscan deformation front and the Carpathians, velocities $V p>6 \mathrm{~km} / \mathrm{s}$ are observed, in the area of the Upper Silesian Block (USB in Fig. 1).

The P-wave velocity data set consists of 10,804 values extracted from 2D seismic models. Velocity versus depth relations calculated separately for Precambrian, Cadomian, Caledonian, and Variscan basement (see Fig. 7e for location) are shown in Fig. 6. Black lines show a linear fit, wide gray bands show the standard deviation, and fit coefficients are given in Table 1. On average, the Precambrian basement is characterized by velocities that are c. $0.2 \mathrm{~km} / \mathrm{s}$ higher then for other areas. The velocity gradient for the Precambrian, Cadomian, and Variscan basements is positive, and for each kilometer depth, the velocity increases by $9-11 \mathrm{~m} / \mathrm{s}$. An exception is the Caledonian basement for which velocity on average decreases by c. $13 \mathrm{~m} / \mathrm{s}$ for each kilometer depth. However, this decrease could be artificial as in the depth range of $6000-10,000 \mathrm{~m}$ velocities are higher, similar to cratonic, while in the depth range of 10,000-13,000 m velocities are lower, similar to the WEP basement. This could indicate that the Caledonian basement represents a transition at domain between the EEC and the WEP, without a characteristic velocity of its own.

\section{Discussion}

Apart from a complex seismic structure, the area of Poland is also associated with significant gravimetric, magnetic, electromagnetic, and heat flow anomalies (Fig. 7). The anomalies indicate major changes of the basement structure and correlate with those evident from seismic data.

The Bouguer anomaly values (Fig. 7b; Królikowski and Petecki 1995; Wybraniec 1999; Bielik et al. 2006) display values as low as $-60 \mathrm{mGal}$ over the TESZ. However, the northeasternmost portion of this gravity minimum overlays an intrabasement feature of the EEC. The adjacent Paleozoic terranes to the southwest and the EEC to the northeast are characterized by near-zero to positive gravity anomalies 

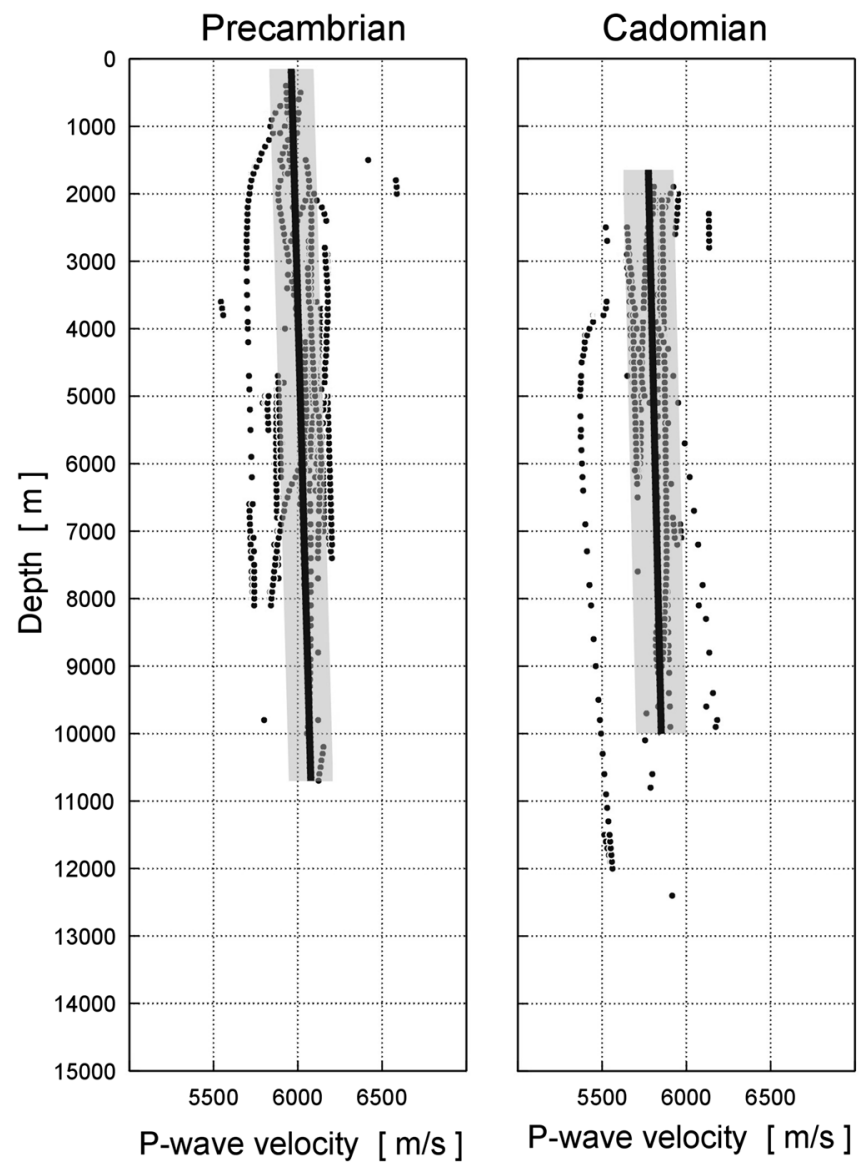

Fig. 6 Velocity versus depth relations for P-wave velocities in the uppermost basement calculated separately for Precambrian, Cadomian, Caledonian, and Variscan basements (see Fig. 7e for location). Black dots show velocities taken from 2D seismic refraction profiles

Table 1 Velocity-depth relations for basement in Poland, $V(z)=a+b z[\mathrm{~m} / \mathrm{s}], z$ - depth $[\mathrm{m}] n$-number of velocity samples

\begin{tabular}{llrrrr}
\hline Area & $a$ & $\Delta a$ & $b \times 10^{4}$ & Depth range $[\mathrm{m}]$ & \multicolumn{1}{c}{$n$} \\
\hline Precambrian & 5959.4 & 129.9 & 109.9 & $150-10,700$ & 1770 \\
Cadomian & 5759.5 & 148.0 & 91.7 & $1650-10,000$ & 968 \\
Caledonian & 6083.1 & 113.4 & -135.5 & $5150-13,500$ & 576 \\
Variscan & 5791.6 & 103.8 & 104.3 & $0-15,000$ & 1680 \\
\hline
\end{tabular}

of up to +20 and $+10 \mathrm{mGal}$, respectively. In the Carpathians, Bouguer anomalies reach values of about $-80 \mathrm{mGal}$.

The magnetic anomalies within the TESZ and in the Carpathians (Fig. 7c; Wybraniec 1999; Petecki et al. 2003) are subdued $( \pm 100 \mathrm{nT})$, which may result from the deeply buried magnetic basement. In contrast, the EEC magnetic anomalies vary at short wavelengths from 1500 to $+1500 \mathrm{nT}$ and correlate well with tectonic features and intrusions.

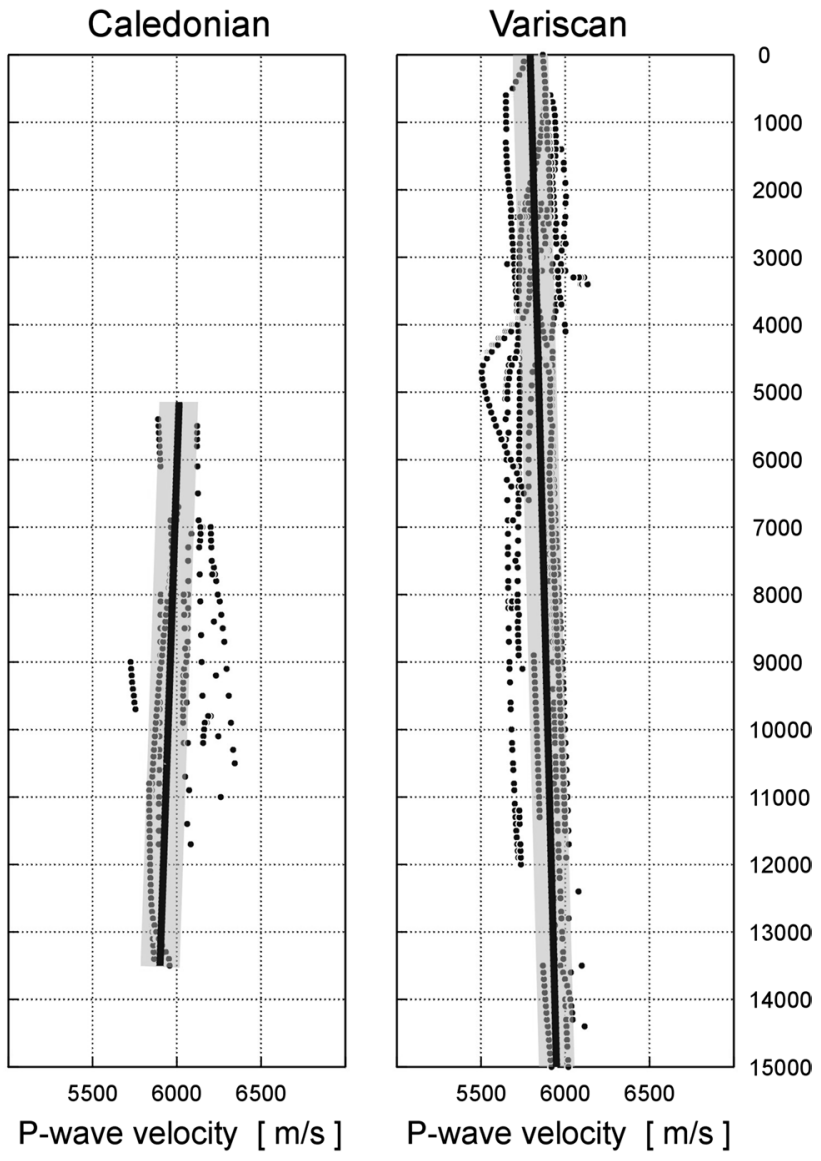

(see Fig. 3c for profiles location), black lines show linear fit and wide gray bands show standard deviation. Fit coefficients are given in Table 1

The area of the Pomeranian part of TESZ is characterized by relatively low velocities of the uppermost basement $(V \mathrm{p} \sim 5.85 \mathrm{~km} / \mathrm{s})$, and correlates well with the location of pronounced sub-horizontal conductor found by the electromagnetic studies (Ernst et al. 2008; Jóźwiak 2013). The conductor has a resistivity as low as $2 \Omega \mathrm{m}$, and is interpreted as Silurian-Cambrian metasediments. Its enhanced conductivity may be caused either by electronic conductors (graphite, alum shale) within Caledonian formations initially rich in coal facies, or by saline fluids (crustal brines) located most likely in the vicinity of deep fault systems (Ernst et al. 2008).

Heat flow variations in the area of Poland (Fig. 7d; Karwasiecka and Bruszewska 1997; Majorowicz et al. 2003) indicate a major change in the thermal regime. In general, the TESZ separates a "cold" EEC area with a low heat flow of c. $40 \mathrm{~mW} / \mathrm{m}^{2}$ to the northeast from a "hot" area with a higher heat flow of $40-70 \mathrm{~mW} / \mathrm{m}^{2}$ in the Paleozoic terranes and Carpathians to the southwest. 
(a)

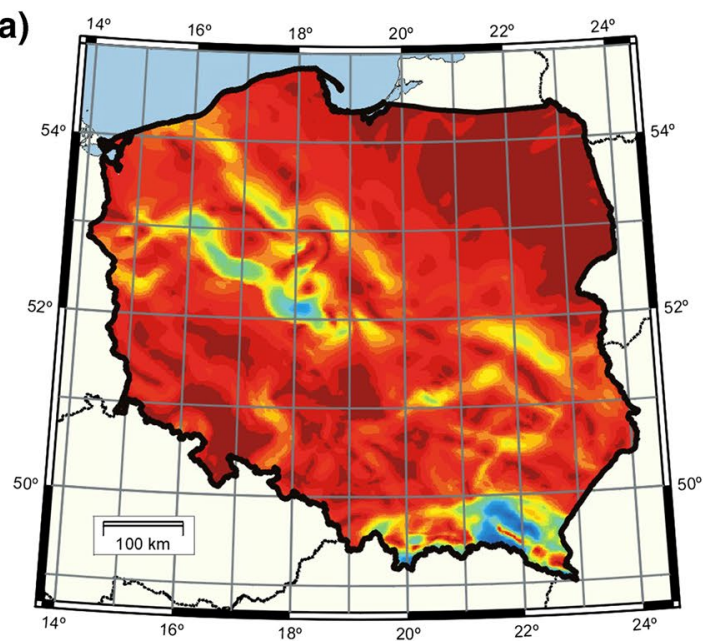

(c)

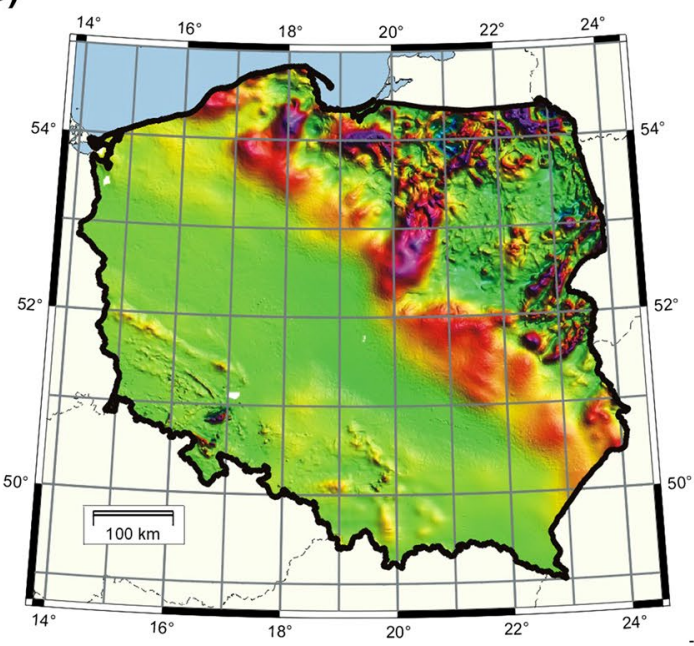

(e)

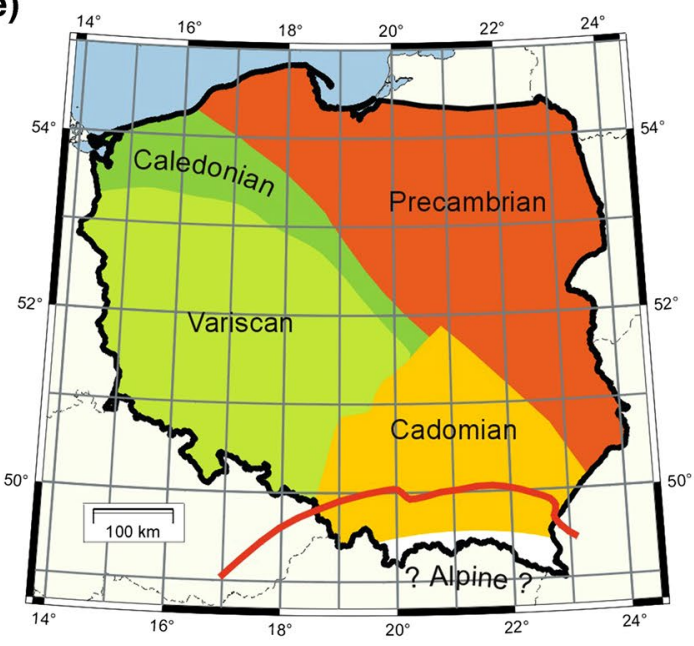

Slope

[ deg ]

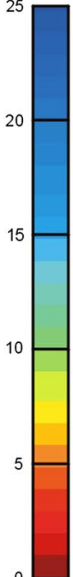

(d)

$\Delta \mathrm{T}[\mathrm{nT}]$ 1000

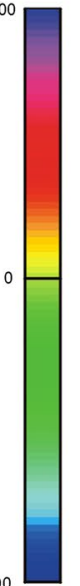

Age

[Ma ]

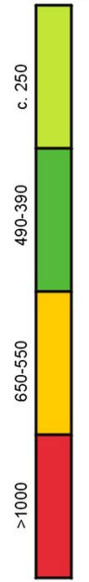

Fig. 7 Summary of geophysical characteristics of the basement in Poland. a Slope of the basement calculated for the basement map presented in this paper (Fig. 4a); slope values are in degree from horizontal. b Bouguer gravity anomaly map of Poland, displayed as harmonic relief image illuminated from NW (Wybraniec 1999). c Magnetic anomaly map of Poland illuminated from SE (Wybraniec 1999; Petecki et al. 2003; Królikowski 2006). d Heat flow map (Kar- (b)
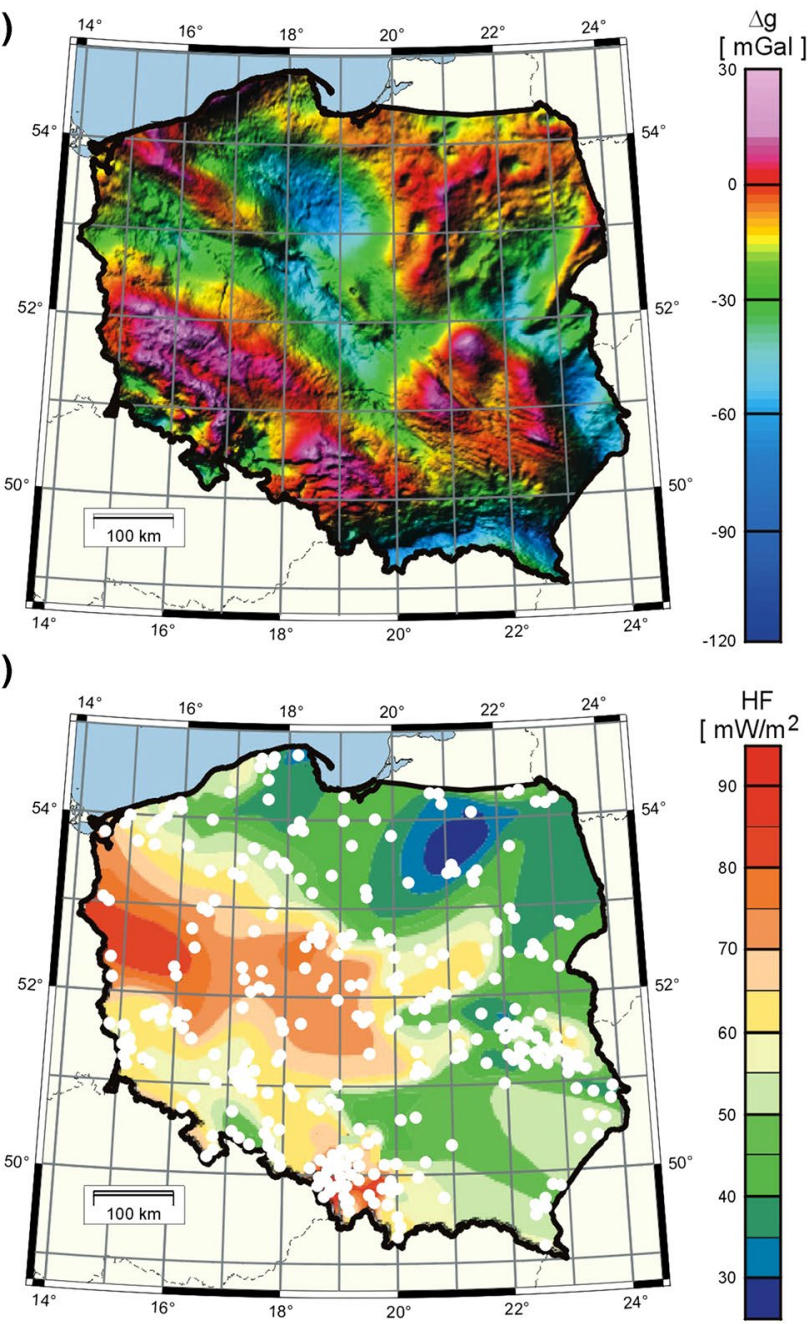

(f)

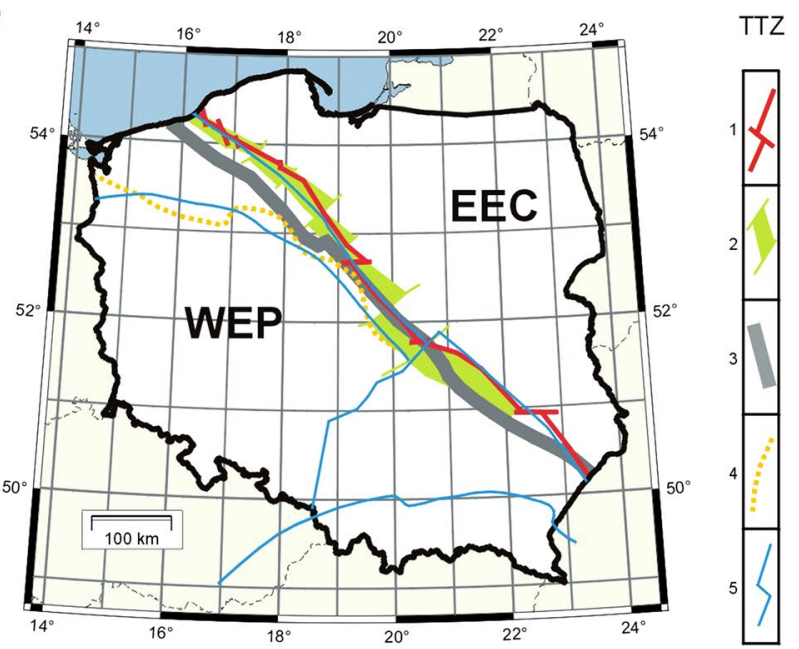

wasiecka and Bruszewska 1997; Majorowicz et al. 2003); white dots show location of wells with temperature logs. e Map of basement consolidation ages of Poland (Karnkowski 2008). f Position of the TTZ in Poland according to various authors: 1 after Pożaryski et al. (1992), 2 after Dadlez (1982), 3 after Narkiewicz et al. (2011), 4 magnetic line, southern margin of the EEC (Pomeranian Massif) after Królikowski (2006), 5 basement borders after Karnkowski (2008) 


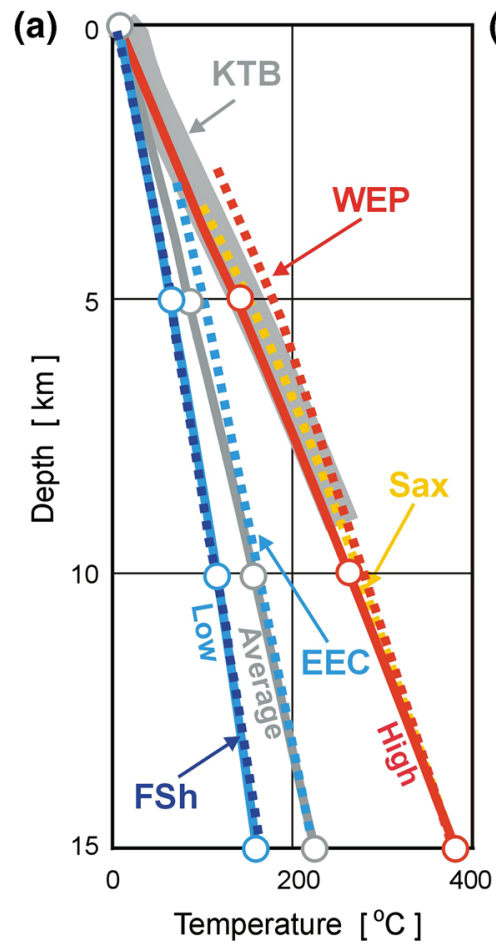

Fig. 8 a Temperature-depth curves for three heat flow provinces: low, average, and high (Christensen and Mooney 1995). For comparison, dashed curves show the temperature-depth for the Saxothuringian area (Sax; Čermák 1995), Western European Platform (WEP) in southwest Poland, East European Craton (EEC) in northeast Poland (Majorowicz et al. 2003), and for the central part of the Fennoscandian Shield (FSh; Kukkonen et al. 2003). Thick gray line extending to about $10 \mathrm{~km}$ shows measured temperature in KTB borehole (Emmer-

The morphology of the geophysical fields, shown in these three maps, coincides in general with the tectonic structure in Poland and has a clear lineation in the NW-SE direction. According to Karnkowski (2008), four principal types of basement structure can be distinguished in the area of Poland: the EEC basement in the northeast, the Caledonian (TESZ) southwest of the EEC edge, the Variscan in SE Poland, and Cadomian basement in the south (Fig. 7e). These features coincide with the map of the basement slope calculated from our basement map (Fig. 7a). Slope values are shown in degree up from horizontal. A small slope is characteristic for the whole area of the EEC, the WEP, and the Cadomian basement. In this map, the TTZ follows the southern edge of the EEC with a slope of $8-12^{\circ}$. The northern edge of the WEP, corresponding to the Variscan deformation front (see Fig. 1), is bounded by a zone with a significant slope of $10-15^{\circ}$. The steepest slope of the basement is observed below the Carpathians, particularly their eastern part, where the basement slope reaches a value of up to c. $20^{\circ}$.

The TTZ in Poland, interpreted as the edge of the EEC, is a NW-SE trending feature. However, its position differs mann and Lauterjung 1997). b Comparison of the linear fit of $V p$ velocities in the uppermost basement in Poland (gray lines) with laboratory data for chosen rocks (Christensen and Mooney 1995): BAS basalt and $Q T Z$ quartzite for high-temperature regime of the WEP, and $B G N$ biotite/tonalite/gneiss, GGN granite/gneiss, GRA granite/ granodiorite, $P H Y$ phyllite and $S L T$ slate for average-temperature regime of the EEP

in details according to different authors (Fig. 7f): Dadlez (1982), Pożaryski et al. (1992), Karnkowski (2008), and Narkiewicz et al. (2011). This variation in location may reach up to $50 \mathrm{~km}$. Additionally, the magnetic line bordering the southern margin of the EEC (Pomeranian Massif) after Królikowski (2006) is shown in Fig. 7f.

In an attempt to interpret basement lithologies for the EEC and the WEP based on P-wave velocities (Fig. 6), we have inferred the most plausible lithologies for the uppermost basement by a comparison with global laboratory data for various rock assemblages (Christensen and Mooney 1995). Lithological candidates for the EEC and the WEP basement are shown in Fig. 8. As a reference temperature, we used temperature-depth curves for low, average, and high heat flow thermal regimes (Fig. 8a; Christensen and Mooney 1995). In the upper $10 \mathrm{~km}$ of the crust, the published temperature-depth curve for the EEC lies close to the average one (Majorowicz et al. 2003), whereas for the Saxothuringian area the temperature-depth curve lies close to the high heat flow curve (Čermák 1995). The high heat flow curve also fits the temperatures measured directly in the KTB borehole down to a depth of about $9100 \mathrm{~m}$ 
(Emmermann and Lauterjung 1997). Near identical to the low thermal regime curve is the temperature for the central part of the Fennoscandian Shield (Kukkonen et al. 2003). The temperature curve of the WEP in southwest Poland (Majorowicz et al. 2003) is higher even then the high regime curve, and is close to curve $\mathrm{D}$ according to Lachenbruch and Sass (1977). Thus, for our comparison between seismic and laboratory data, we used the "hot" regime for the WEP and the "average" regime for the EEC.

In Fig. 8b, laboratory data for a high-temperature regime are shown for various rock assemblages. The observed velocities in the WEP basement are close to basalt and quartzite, particularly for the depth range of $10-15 \mathrm{~km}$. Granite/gneiss and biotite/tonalite/gneiss have higher velocities. On the other hand, gneisses are actually the most common lithology exposed in that area (e.g., Mueller 1995), and borehole data from the basement of the Wolsztyn-Leszno High show the occurrence of phyllites.

The relatively low-velocity basement of the TESZ can be interpreted as an extensive pile of low-grade metasediments (e.g., metagraywackes). Alternatively, it may also represent a gneiss complex, if intense NW-SE-oriented anisotropy is assumed consistent with the regional geological context (Jarosiński and Dąbrowski 2006; Środa 2006). Anisotropy has not been taken into account in Fig. 8a, but it should be noted that according to Christensen and Mooney (1995), anisotropy can reach values ranging from 1 to $5 \%$ (e.g., granite/granodiorite, granite/gneiss, basalt, metagraywacke, quartzite) to $10-20 \%$ (e.g., phyllite, slate, amphibolite) in basement rocks.

Close to the margin of the EEC, there is no direct information about the type of rocks and the age of the basement. However, in the northeastern EEC, drill holes have provided considerable information about the Precambrian basement (Ryka 1984; Skridlaite and Motuza 2001). Accordingly, the Palaeoproterozoic crystalline basement of the EEC is mostly composed of granulites, migmatites, anorthosites, and granite/gneisses (e.g., Ryka 1984; Skridlaite and Motuza 2001).

\section{Conclusions}

In Poland, the basement in the TESZ and the Carpathians is not reached by boreholes, so its depth and velocity are available only from seismic profiles and can be inferred indirectly by a joint integration of geophysical data. Using all available data, a basement depth map and the distribution of seismic $\mathrm{P}$-wave velocity in the uppermost basement for the area of Poland were created.

The new results of this paper, regarding the seismic basement in the area of Poland, are displayed in three maps: the basement depth map (Fig. 4a), the P-wave velocity map of the uppermost basement (Fig. 4b), and the map of the basement slope (Fig. 7a).

The basement depth map is compared with three basement maps published earlier: global by Laske and Masters (1997), European crustal model EPcrust by Molinari and Morelli (2011), and crustal model for Western and Central Europe by Tesauro et al. (2008). The comparison shows many similarities, particularly for the EEC and the WEP (Fig. 5). In the TESZ in NW Poland, large differences of up to $6-9 \mathrm{~km}$ could be explained by another discrimination between the crystalline (Precambrian) and consolidated (Paleozoic) types of crust. Two types of crust are reflected in basement velocities: velocities $V p>6 \mathrm{~km} / \mathrm{s}$ are observed in the EEC, north of the TTZ, while southwest of the TTZ velocities of the uppermost basement are significantly lower, being $V p<6 \mathrm{~km} / \mathrm{s}$. The continuation of the structures to the northwest is discussed for the Central European Basin System (Scheck-Wenderoth and Maystrenko 2013) and the Danish area and surroundings (Lassen and Thybo 2012).

Differences of basement velocities for the EEC and the WEP correspond to the density differentiation of both provinces. The EEC basement density of $2.71-2.75 \mathrm{~g} / \mathrm{cm}^{3}$ was modeled across the Skagerrak Graben (Lassen and Thybo 2012). In NW Poland, Królikowski and Petecki (2002) obtained a 2D density model along the LT-7 profile with basement values of $2.68 \mathrm{~g} / \mathrm{cm}^{3}$ for WEP and $2.82 \mathrm{~g} / \mathrm{cm}^{3}$ for EEP. Similar values were applied by Maystrenko and Scheck-Wenderoth (2013) in a 3D density model of the Central European Basin System and adjacent areas: 2.79$2.83 \mathrm{~g} / \mathrm{cm}^{3}$ for EEC basement, $2.67 \mathrm{~g} / \mathrm{cm}^{3}$ for Variscan granitoids, and $2.79 \mathrm{~g} / \mathrm{cm}^{3}$ for Variscan upper crust.

Slightly smaller basement densities were found in Poland in the eastern portion of EEC. The top part of the crystalline Precambrian basement has excellent density evidence thanks to a number of sampled boreholes, deeply penetrating the crystalline basement. Only these boreholes, which penetrate the crystalline basement into depths of at least several tens of meters, were recognized as representative ones, because of the weathering of the surface of the crystalline basement in ancient times and some other processes leading to a decrease in the density at several meters depths. The top of the Precambrian basement represents the "granitoid type" which consists mostly of gneisses, with an average density of $2.72 \mathrm{~g} / \mathrm{cm}^{3}$ (Krysiński et al. 2009). Similar basement density values, c. $2.75 \mathrm{~g} / \mathrm{cm}^{3}$, were found from $2 \mathrm{D}$ gravity modeling along the seismic profile POLCRUST-01 in SE Poland (Narkiewicz et al. 2015). A constant density of $2.70 \mathrm{~g} / \mathrm{cm}^{3}$, corresponding to rocks in the top of the crystalline complex of old cratons, was assigned to rocks of the crystalline basement of the EEC in SE Poland by Grabowska and Bojdys (2001).

The map of the basement slope (Fig. 7a) shows two significant features running in NW-SE directions through 
central Poland: the northern one could be related to the edge of the EEC, while the southern one to the Variscan deformation front (see Fig. 1). The edge of the EEC in Poland, the Teisseyre-Tornquist Zone (TTZ), continues in SW Scandinavia as the Sorgenfrei-Tornquist Zone (STZ). This boundary between Baltica and Phanerozoic Europe is well visible in the basement, Moho depth, as well as in lithospheric thickness (e.g., Lassen and Thybo 2012; ScheckWenderoth and Maystrenko 2013; Grad et al. 2009, 2014; Knapmeyer-Endrun et al. 2014; Wilde-Piórko et al. 2010; Puziewicz et al. 2006; Gregersen et al. 2002; Geissler et al. 2010). The gravity modeling suggests a very small density value in the uppermost mantle $3.11 \mathrm{~g} / \mathrm{cm}^{3}$ below the younger area of WEP, while for the older area of EEC, it is $3.3 \mathrm{~g} / \mathrm{cm}^{3}$ (e.g., Krysiński et al. 2009).

The position of the TTZ in Poland differs according to different geological and geophysical interpretations (Fig. 7f). As suggested by Karnkowski (2008), the tectonic sub-division in the area of Poland should be done at three levels: sub-Cenozoic, sub-Permian, and at the crystalline/ consolidated basement. Within these levels, the range of tectonic units could be different. The edge of the EEC in the basement level is relatively clear and defines the southwestern range of the craton. However, another criterion in the continental scale could be one more-crustal criterion, e.g., range of the high velocity lower crust beneath EEC (Grad et al. 2002, 2003a, b, 2008).

Finally, the map of seismic basement depth and basement P-wave velocity map in the area of Poland will be an important contribution to the digital 3D seismic model of the crust and uppermost mantle. Together with detailed data about geometry and velocities in the sedimentary cover (Grad and Polkowski 2012; Polkowski and Grad 2015), and a huge set of regional seismic refraction profiles, they permit for the creation of a detailed model for seismic local, regional, and global studies (Malinowski et al. 2013; Grad et al. 2015).

The basement depth and uppermost basement P-wave velocity maps for the area of Poland, filtered with $30-\mathrm{km}-$ radius boxcar filter, as shown in Fig. 4, can be found in digital form at: http://www.igf.fuw.edu.pl/seismic/.

Acknowledgments The National Science Centre Poland provided financial support for this work through a NCN grant DEC-2011/02/A/ ST10/00284. The public domain GMT software (Wessel and Smith 1991, 1998) has been used to produce maps.

Open Access This article is distributed under the terms of the Creative Commons Attribution 4.0 International License (http://creativecommons.org/licenses/by/4.0/), which permits unrestricted use, distribution, and reproduction in any medium, provided you give appropriate credit to the original author(s) and the source, provide a link to the Creative Commons license, and indicate if changes were made.

\section{References}

Berthelsen A (1998) The Tornquist Zone northwest of the Carpathians: an intraplate-pseudosuture. Geol Fören Stockh Förh 120:223-230

Bielik M, Kloska K, Meurers B, Švancara J, Wybraniec S, Fancsik T, Grad M, Grand T, Guterch A, Katona M, Królikowski C, Mikuška J, Pašteka R, Petecki Z, Polechońska O, Ruess D, Szalaiová V, Šefara J, Vozár J (2006) Gravity anomaly map of the CELEBRATION 2000 region. Geol Carpath 57(3):145-156

Bogdanova S, Gorbatschev R, Grad M, Janik T, Guterch A, Kozlovskaya E, Motuza G, Skridlaite G, Starostenko V, Taran L, EUROBRIDGE and POLONAISE Working Groups (2006) EUROBRIDGE: new insight into the geodynamic evolution of the East European Craton. In: Gee DG, Stephenson RA (eds) European lithosphere dynamics, vol 32. Geological Society of London, Memoirs, pp 599-625

Bogdanova S, Bingen B, Gorbatschev R, Kheraskova TN, Kozlov VI, Puchkov VN, Volozh YuA (2008) The East European Craton (Baltica) before and during the assembly of Rodinia. Prec Res 160:23-45. doi:10.1016/j.precamres.2007.04.024

Čermák V (1995) A geothermal model of the Central Segment of the European Geotraverse. Tectonophysics 244:51-55. doi:10.1016/0040-1951(94)00216-V

Christensen NI, Mooney WD (1995) Seismic velocity structure and composition of the continental crust: a global view. J Geophys Res 100(B6):9761-9788. doi:10.1029/95JB00259

Cymerman Z (2007) Does the Mazury dextral shear zone exist? Prz Geol 55:157-167 (in Polish with English abstract)

Czuba W, Grad M, Luosto U, Motuza G, Nasedkin Nasedkin, POLONAISE P5 Working Group (2001) Crustal structure of the East European Craton along POLONAISE ' 95 P5 profile. Acta Geophys Pol 49:145-168

Dadlez R (1982) Permian-Mesozoic tectonics versus basement fractures along the Teisseyre-Tornquiste Zone in the territory of Poland. Kwart Geol 26:273-284 (in Polish with English abstract)

Dadlez R (2006) The Polish Basin-relationship between the crystalline, consolidated and sedimentary crust. Geol Quart 50(1):43-58

Dadlez R, Grad M, Guterch A (2005) Crustal structure below the Polish Basin: is it composed of proximal terranes derived from Baltica? Tectonophysics 411:111-128. doi:10.1016/j. tecto.2005.09.004

Emmermann R, Lauterjung J (1997) The German continental deep drilling program KTB: overview and major results. J Geophys Res 102(B8):18179-18201. doi:10.1029/96JB03945

Ernst T, Brasse H, Cerv V, Hoffmann N, Jankowski J, Jozwiak W, Kreutzmann A, Neska A, Palshin N (2008) Electromagnetic images of the deep structure of the Trans-European suture Zone beneath Polish Pomerania. Geophys Res Lett 35:L15307. doi:10 .1029/2008GL034610

Geissler WH, Sodoudi F, Kind R (2010) Thickness of the central and eastern European lithosphere as seen by $\mathrm{S}$ receiver functions. Geophys J Int 181:604-634

Golonka J, Ślączka A, Picha F (2003) Geodynamic evolution of the orogen: the West Carpathians and Ouachitas case study. Ann Soc Geol Pol 75:145-167

Grabowska T, Bojdys G (2001) The border of the East-European Craton in southeastern Poland based on gravity and magnetic data. Terra Nova 13:92-98

Grad M, Polkowski M (2012) Seismic wave velocities in the sedimentary cover of Poland: borehole data compilation. Acta Geophys 60:985-1006. doi:10.2478/s11600-012-0022-z 
Grad M, Trung Doan T, Klimkowski W (1990) Seismic models of sedimentary cover of the Precambrian and Palaeozoic platforms in Poland. Kwart Geol 34:393-410 (in Polish with English abstract)

Grad M, Trung Doan T, Klimkowski W (1991) Seismic models of sedimentary cover of the Precambrian and Paleozoic platforms in Poland. Publs Inst Geophys Pol Acad Sc A-19(236):125-145

Grad M, Janik T, Yliniemi J, Guterch A, Luosto U, Tiira T, Komminaho K, Środa P, Höing K, Makris J, Lund CE (1999) Crustal structure of the Mid-Polish Trough beneath the TTZ seismic profile. Tectonophysics 314:145-160

Grad M, Guterch A, Mazur S (2002) Seismic refraction evidence for crustal structure in the central part of the Trans-European Suture Zone in Poland. In: Winchester JA, Pharaoh TC, Verniers J (eds) Palaeozoic amalgamation of Central Europe. Geol Soc Lond Sp Pub 201:295-309

Grad M, Jensen SL, Keller GR, Guterch A, Thybo H, Janik T, Tiira T, Yliniemi J, Luosto U, Motuza G, Nasedkin V, Czuba W, Gaczyński E, Środa P, Miller KC, Wilde-Piórko M, Komminaho K, Jacyna J, Korabliova L (2003a) Crustal structure of the Trans-European suture zone region along POLONAISE'97 seismic profile P4. J Geophys Res 108(B11):2541. doi:10.1029/200 3JB002426

Grad M, Špičák A, Keller GR, Guterch A, Brož M, Hegedús E, SUDETES 2003 Working Group (2003b) SUDETES 2003 seismic experiment. Stud Geophys Geod 47:681-689

Grad M, Guterch A, Polkowska-Purys A (2005) Crustal structure of the Trans-European suture zone in Central Poland-reinterpretation of the LT-2, LT-4 and LT-5 deep seismic sounding profiles. Geol Quart 49:243-252

Grad M, Guterch A, Keller GR, Janik T, Hegedûs E, Vozár J, Ślączka A, Tiira T, Yliniemi J (2006) Lithospheric structure beneath trans-Carpathian transect from Precambrian platform to Pannonian basin: CELEBRATION 2000 seismic profile CEL05. J Geophys Res 111:B03301. doi:10.1029/2005JB003647

Grad M, Guterch A, Mazur S, Keller GR, Špičák A, Hrubcová P, Geissler WH (2008) Lithospheric structure of the Bohemian Massif and adjacent Variscan belt in central Europe based on profile S01 from the SUDETES 2003 experiment. J Geophys Res 113:B10304. doi:10.1029/2007JB005497

Grad M, Brüickl E, Majdański M, Behm M, Guterch A, CELEBRATION 2000 Working Group, ALP 202 Working Group (2009) Crustal structure of the Eastern Alps and their foreland: seismic model beneath the CEL10/Alp04 profile and tectonic implications. Geophys J Int 177:279-295

Grad M, Tiira T, Olsson S, Komminaho K (2014) Seismic lithosphere-asthenosphere boundary beneath the Baltic Shield. GFF 136:581-598. doi:10.1080/11035897.2014.959042

Grad M, Polkowski M, Wilde-Piórko M, Suchcicki J, Arant T (2015) Passive seismic experiment " 13 BB star" in the margin of the East European craton, northern Poland. Acta Geophys 63(2):352-373. doi:10.1515/acgeo-2015-0006

Gregersen S, Voss P, TOR Working Group (2002) Summary of project TOR: delineation of a stepwise, sharp, deep lithosphere transition across Germany-Denmark-Sweden. Tectonophysics 360:61-73

Guterch A, Grad M (2006) Lithospheric structure of the TESZ in Poland based on modern seismic experiments. Geol Quart 50:23-32

Guterch A, Grad M, Janik T, Materzok R, Luosto U, Yliniemi J, Lück E, Schulze A, Förste K (1994) Crustal structure of the transition zone between Precambrian and Variscan Europe from new seismic data along LT-7 profile (NW Poland and eastern Germany). C R Acad Sci Paris 319:1489-1496

Guterch A, Grad M, Thybo H, Keller Keller, POLONAISE Working Group (1999) POLONAISE'97—an international seismic experiment between Precambrian and Variscan Europe in Poland. Tectonophysics 314:101-121

Guterch A, Grad M, Keller GR, Posgay K, Vozár J, Špičák A, Brückl E, Hajnal Z, Thybo H, Selvi O, CELEBRATION 2000 Working Group (2003) CELEBRATION 2000 seismic experiment. Stud Geophys Geod 47:659-669

Janik T, Yliniemi J, Grad M, Thybo H, Tiira T, POLONAISE P2 Working Group (2002) Crustal structure across the TESZ along POLONAISE '97 seismic profile P2 in NW Poland. Tectonophysics 360:129-152

Janik T, Grad M, Guterch A, Dadlez R, Yliniemi J, Tiira T, Gaczyński E, CELEBRATION 2000 Working Group (2005) Lithospheric structure of the trans-European suture zone along the TTZ \& CEL03 seismic profiles (from NW to SE Poland). Tectonophysics 411:129-155. doi:10.1016/j.tecto.2005.09.005

Janik T, Grad M, Guterch A, CELEBRATION 2000 Working Group (2009) Seismic structure of the lithosphere between the East European Craton and the Carpathians from the net of CELEBRATION 2000 profiles in SE Poland. Geol Quart 53:141-158

Jansen SL, Janik T, Thybo H, POLONAISE Working Group (1999) Seismic structure of the Palaeozoic Platform along POLONAISE'97 profile P1 in southwestern Poland. Tectonophysics 314:123-143

Jarosiński M, Dąbrowski M (2006) Rheological models of the lithosphere across the Trans-European suture zone in northern and western part of Poland. Prace PIG 188:143-166 (in Polish with English summary)

Jóźwiak W (2013) Electromagnetic study of lithospheric structure in the marginal zone of East European Craton in NW Poland. Acta Geophys 61(5):1101-1129. doi:10.2478/s11600-013-0127-z

Karnkowski PH (2008) Tectonic subdivision of Poland: Polish Lowlands. Prz Geol 56:895-903 (in Polish with English abstract)

Karwasiecka AM, Bruszewska B (1997) Density of the surface Earth's heat flow on the area of Poland (Gęstość powierzchniowego strumienia cieplnego ziemi na obszarze Polski). Centr Arch PIG, Pol Geol Inst No060:21/98, Warsaw (in Polish)

Knapmeyer-Endrun B, Krüger F, Legendre CP, Geissler WH, PASSEQ Working Group (2014) Moho depth across the TransEuropean suture zone from P- and S-receiver functions. Geophys J Int 197:1048-1075. doi:10.1093/gji/ggu035

Kotański Z (ed) (1997) Geological atlas of Poland: geological maps of horizontal cutting 1:750000. Państw Inst Geol, Warsaw

Królikowski C (2006) Crustal-scale complexity of the contact zone between the Palaeozoic platform and the East-European Craton in the NW Poland. Geol Quart 50:33-42

Królikowski C, Petecki Z (1995) Gravimetric Atlas of Poland. Pol Geolog Inst, Warsaw

Królikowski C, Petecki Z (2002) Lithospheric structure across the Trans-European Suture Zone in NW Poland based on gravity data interpretation. Geol Quart 46:235-245

Krysiński L, Grad M, Wybraniec S (2009) Searching for regional crustal velocity-density relations with the use of 2-D gravity modelling — Central Europe case. Pure Appl Geophys 166:19131936. doi:10.1007/s00024-009-0526-x

Krzywiec P (2006a) Triassic-Jurassic evolution of the Pomeranian segment of the Mid-Polish trough-basement tectonics and subsidence patterns. Geol Quart 50:139-150

Krzywiec P (2006b) Structural inversion of the Pomeranian and Kuiavian segments of the mid-polish trough-lateral variations in timing and structural style. Geol Quart 50:151-168

Kukkonen IT, Kinnunen KA, Peltonen P (2003) Mantle xenoliths and thick lithosphere in the Fennoscandian Shield. Phys Chem Earth 28:349-360

Lachenbruch AH, Sass JH (1977) Heat flow and the thermal regime of the crust. In: Heacock JG (ed) The Earth;s crust: its nature 
and physical properties. Geophys Monogr Ser 20:626-675 AGU, Washington, DC

Laske G, Masters G (1997) A global digital map of sediment thickness. EOS Trans AGU 78:F483

Lassen A, Thybo H (2012) Neoproterozoic and palaeozoic evolution of SW Scandinavia based on integrated seismic interpretation. Precambr Res 204-205:75-104

Majdański M, Grad M, Guterch A, SUDETES 2003 Working Group (2006) 2-D seismic tomographic and ray tracing modelling of the crustal structure across the Sudetes mountains basing on SUDETES 2003 experiment data. Tectonophysics 413:249-269. doi:10.1016/j.tecto.2005.10.042

Majorowicz J, Čermak V, Šafanda J, Krzywiec P, Wróblewska M, Guterch A, Grad M (2003) Heat flow models across the TransEuropean suture zone in the area of the POLONAISE'97 seismic experiment. Phys Chem Earth 28:375-391

Malinowski M, Żelaźniewicz A, Grad M, Guterch A, Janik T (2005) Seismic and geological structure of the crust in the transition from Baltica to Palaeozoic Europe in SE Poland-CELEBRATION 2000 experiment, profile CEL02. Tectonophysics 401:5577. doi:10.1016/j.tecto.2005.03.011

Malinowski M, Guterch A, Narkiewicz M, Probulski J, Maksym A, Majdański M, Środa P, Czuba W, Gaczyński E, Grad M, Janik T, Jankowski L, Adamczyk A (2013) Deep seismic reflection profile in Central Europe reveals complex pattern of Paleozoic and Alpine accretion at the East European Craton margin. Geophys Res Lett 40:3841-3846

Małolepszy Z (2005) Three-dimensional geological maps. In: Ostaficzuk $S$ (ed) The current role of geological mapping in geosciences. NATO Sci Ser 56:215-224, Springer

Maystrenko YP, Scheck-Wenderoth M (2013) 3D lithosphere-scale density model of the Central European Basin System and adjacent areas. Tectonophysics 601:53-77

Mazur S, Scheck-Wenderoth M, Krzywiec P (2005) Different modes of the Late Cretaceous-Early Tertiary inversion in the North German and Polish basins. Int J Earth Sci 94:782-798

Michalak J (2004) DEM data obtained from the Shuttle Radar Topography Mission-SRTM-3. Ann Geomat 2:34-44

Molinari I, Morelli A (2011) EPcrust: a reference crustal model for the european plate. Geophys J Int 185:352-364. doi:10.1111/j.1365-246X.2011.04940.x

Mueller HJ (1995) Modelling of the lower crust by simulation of the in situ conditions: an example from Saxonian Erzgebirge. Phys Earth Planet Inter 92:3-15. doi:10.1016/0031-9201(95)03055-2

Narkiewicz M (2012) Tectonic subdivision of Poland-critical and polemic remarks. Prz Geol 60:485-489 (in Polish)

Narkiewicz M, Dadlez R (2008) Geological regional subdivision of Poland: general guidelines and proposed schemes of sub-Cenozoic and sub-Permian units. Prz Geol 56:391-397 (in Polish with English abstract)

Narkiewicz M, Grad M, Guterch A, Janik T (2011) Crustal seismic velocity structure of southern Poland: preserved memory of a pre-Devonian terrane accretion at the East European Platform margin. Geol Mag 148:191-210. doi:10.1017/ S001675681000049X

Narkiewicz M, Maksym A, Malinowski M, Grad M, Guterch A, Probulski J, Janik T, Majdański M, Środa P, Czuba W, Gaczyński E, Jankowski L (2015) Transcurrent nature of the Teisseyre-Tornquist Zone in Central Europe: results of the POLCRUST-01 deep reflection seismic profile. Int J Earth Sci 104:775-796. doi:10.1007/ s00531-014-1116-4

Nita J, Małolepszy Z, Chybiorz R (2007) A Digital Terrain Model in visualization and interpretation of geological and geomorphological settings. Prz Geol 55:511-520 (in Polish with English abstract)
Petecki Z, Polechońska O, Cieśla E, Wybraniec S (2003) Magnetic map of Poland, scale 1:500,000. Pol Geol Ins, Warsaw

Pharaoh TC (1999) Palaeozoic terranes and their lithospheric boundaries within the Trans-European Suture Zone (TESZ): a review. Tectonophysics 314:17-41

Piotrowska K, Ostaficzuk S, Małolepszy Z, Rossa M (2005) The numerical spatial model (3D) of geological structure of Polandfrom $6000 \mathrm{~m}$ to $500 \mathrm{~m}$ b.s.1. Prz Geol 53:961-966

Polkowski M, Grad M (2015) Seismic wave velocities in deep sediments in Poland: borehole and refraction data compilation. Acta Geophys 63(3):698-714. doi:10.1016/ B978-0-444-53802-4.00015-4

Pożaryski W, Dembowski Z (1983) Geological map of Poland and neighbouring countries without Cenozoic, Mesozoic and Permian deposits (1:1000000). Geol Inst, Warsaw

Pożaryski W, Grocholski A, Tomczyk H, Karnkowski P, Moryc W (1992) The tectonic map of Poland in the Variscan epoch. Prz Geol 40:643-651

Puziewicz J (2006) Lower crust and uppermost mantle rocks in the area of the POLONAISE'97 seismic experiment-petrologicseismic models. Prace PIG 188:53-68 (in Polish with English abstract and summary)

Ryka W (1984) Deep structure of the Precambrian basement of the Precambrian platform in Poland. Publ Inst Geophys Pol Acad Sci A 13(160):87-100

Scheck-Wenderoth M, Maystrenko YP (2013) Deep control on shallow heat in sedimentary basins. Energy Procedia 40:226-275

Schweitzer J (1995) Blockage of regional seismic waves by the Teisseyre-Tornquist Zone. Geophys J Int 123:260-276

Skorupa J (1974) Seismic velocity map of Poland 1:500000. Wyd Geol Warsaw

Skridlaite G, Motuza G (2001) Precambrian domains in the Lithuania: evidence of terrane tectonics. Tectonophysics 339:113-133

Skridlaitė G, Bogdanova S, Page L (2006) Mesoproterozoic events in eastern and central Lithuania as recorded by ${ }^{40} \mathrm{Ar} /{ }^{39} \mathrm{Ar}$ ages. Baltica 19:91-98

Środa P (2006) Seismic anisotropy of the upper crust in southeastern Poland - Effect of the compressional deformation at the EEC margin: results of CELEBRATION 2000 seismic data inversion. Geophys Res Lett 33:L22302. doi:10.1029/2006GL027701

Środa P, POLONAISE Working Group 1999 (1999) P- and S-wave velocity model of the southwestern margin of the Precambrian East European Craton; POLONAISE'97, profile P3. Tectonophysics 314:175-192

Środa P, Czuba W, Grad M, Guterch A, Tokarski AK, Janik T, Rauch M, Keller GR, Hegedűs E, Vozár J, CELEBRATION 2000 Working Group (2006) Crustal and upper mantle structure of the Western Carpathians from CELEBRATION 2000 profiles CEL01 and CEL04: seismic models and geological implications. Geophys J Int 167:737. doi:10.1111/j.1365-246X.2006.03104.x

Starostenko V, Janik T, Kolomiyets K, Czuba W, Środa P, Grad M, Kovács I, Stephenson R, Lysynchuk D, Thybo H, Artemieva IM, Omelchenko V, Gintov O, Kutas R, Gryn D, Guterch A, Hegedús E, Komminaho K, Legostaeva O, Tiira T, Tolkunov A (2013) Seismic velocity model of the crust and upper mantle along profile PANCAKE across the Carpathians between the Pannonian Basin and the East European Craton. Tectonophysics 608:10491072. doi:10.1016/j.tecto.2013.08.004

Stefaniuk M, Klityński W (2007) Magnetotelluric Map of Carpathians. In: Lemberger M, Ostrowski C, Stefaniuk M, Petecki Z, Królikowski C, Kosobudzka I, Wróblewska M (eds) Geophysical Atlas of the Carpathians. CAG PIG, Warszawa

Tesauro M, Kaban MK, Cloetingh SAPL (2008) EuCRUST-07: a new reference model for the European crust. Geophys Res Lett 35:L05313. doi:10.1029/2007GL032244 
Wessel P, Smith WHF (1991) Free software helps map and display data. EOS Trans AGU 72(41):445-446

Wessel P, Smith WHF (1998) New, improved version of Generic Mapping Tools released. EOS Trans AGU 79(47):579

Wilde-Piórko M, Świeczak M, Grad M, Majdański M (2010) Integrated seismic model of the crust and upper mantle of the Trans-European Suture zone between the Precambrian craton and Phanerozoic terranes in Central Europe. Tectonophysics 481:108-115. doi:10.1016/j.tecto.2009.05.002

Winchester JA, PACE TMR Network Team (2002) Palaeozoic amalgamation of Central Europe: new results from recent geological and geophysical investigations. Tectonophysics 360:5-21

Winchester JA, Pharaoh TC, Verniers J (2002) Palaeozoic amalgamation of Central Europe: an introduction and synthesis of new results from recent geological and geophysical investigations. In:
Winchester JA, Pharaoh TC, Verniers J (eds) Palaeozoic Amalgamation of Central Europe, Geol Soc London Sp Pub 201, pp 1-18

Wybraniec S (1999) Transformations and visualization of potential field data. Pol Geol Inst Sp Pap 1:1-88

Żelaźniewicz A, Aleksandrowski P, Buła Z, Karnkowski PH, Konon A, Oszczypko N, Ślączka A, Żaba J, Żytko K (2011) Tectonic subdivision of Poland. KNG PAN, Wrocław, pp 1-60 (in Polish)

Ziegler PA (1990) Geological atlas of Western and Central Europe, 2nd edn. Shell Internationale Petroleum Maatschappij BV, Den Haag

Zielhuis A, Nolet G (1994) The deep seismic expression of an ancient plate boundary in Europe. Science 265:79-81 